Article

\title{
Physiological Response of Corynebacterium glutamicum to Indole
}

\author{
Tatjana Walter ${ }^{1}{ }^{\mathbb{D}}$, Kareen H. Veldmann ${ }^{1}$, Susanne Götker ${ }^{1}$, Tobias Busche ${ }^{2}$, Christian Rückert ${ }^{2}$, \\ Arman Beyraghdar Kashkooli ${ }^{3,+}$, Jannik Paulus ${ }^{4}$, Katarina Cankar ${ }^{3}$ and Volker F. Wendisch ${ }^{1, *(\mathbb{D}}$ \\ 1 Genetics of Prokaryotes, Faculty of Biology and CeBiTec, Bielefeld University, 33615 Bielefeld, Germany; \\ t.walter@uni-bielefeld.de (T.W.); veldmann.kareen@gmx.de (K.H.V.); sgoetker@cebitec.uni-bielefeld.de (S.G.) \\ 2 Center for Biotechnology, Bielefeld University, 33615 Bielefeld, Germany; \\ tbusche@cebitec.uni-bielefeld.de (T.B.); cruecker@CeBiTec.Uni-Bielefeld.DE (C.R.) \\ 3 BU Bioscience, Wageningen University \& Research, 6700AA Wageningen, The Netherlands; \\ a.beyraghdar@yahoo.com (A.B.K.); katarina.cankar@wur.nl (K.C.) \\ 4 Organic and Bioorganic Chemistry, Department of Chemistry, Bielefeld University, \\ 33615 Bielefeld, Germany; j.paulus@uni-bielefeld.de \\ * Correspondence: volker.wendisch@uni-bielefeld.de \\ + Current address: Department of Horticultural Science, Faculty of Agriculture, Tarbiat Modares University, \\ 14115-111 Tehran, Iran.
}

Received: 23 November 2020; Accepted: 5 December 2020; Published: 8 December 2020

check for updates

\begin{abstract}
The aromatic heterocyclic compound indole is widely spread in nature. Due to its floral odor indole finds application in dairy, flavor, and fragrance products. Indole is an inter- and intracellular signaling molecule influencing cell division, sporulation, or virulence in some bacteria that synthesize it from tryptophan by tryptophanase. Corynebacterium glutamicum that is used for the industrial production of amino acids including tryptophan lacks tryptophanase. To test if indole is metabolized by C. glutamicum or has a regulatory role, the physiological response to indole by this bacterium was studied. As shown by RNAseq analysis, indole, which inhibited growth at low concentrations, increased expression of genes involved in the metabolism of iron, copper, and aromatic compounds. In part, this may be due to iron reduction as indole was shown to reduce $\mathrm{Fe}^{3+}$ to $\mathrm{Fe}^{2+}$ in the culture medium. Mutants with improved tolerance to indole were selected by adaptive laboratory evolution. Among the mutations identified by genome sequencing, mutations in three transcriptional regulator genes were demonstrated to be causal for increased indole tolerance. These code for the regulator of iron homeostasis DtxR, the regulator of oxidative stress response RosR, and the hitherto uncharacterized Cg3388. Gel mobility shift analysis revealed that Cg3388 binds to the intergenic region between its own gene and the iolT2-rhcM2D2 operon encoding inositol uptake system IolT2, maleylacetate reductase, and catechol 1,2-dioxygenase. Increased RNA levels of rhcM2 in a $\operatorname{cg} 3388$ deletion strain indicated that $\mathrm{Cg} 3388$ acts as repressor. Indole, hydroquinone, and 1,2,4-trihydroxybenzene may function as inducers of the iolT2-rhcM2D2 operon in vivo as they interfered with DNA binding of Cg3388 at physiological concentrations in vitro. Cg3388 was named IhtR.
\end{abstract}

Keywords: Corynebacterium glutamicum; amino acids; indole; adaptive laboratory evolution; iron homeostasis; oxidative stress; aromatic compound catabolism

\section{Introduction}

Indole is a bioactive aromatic compound and used as flavor and fragrance in the cosmetics (e.g., perfume) and food (e.g., dairy products) industries because of its floral odor which is typical for jasmine [1]. The hormone indole-3-acetic acid facilitates plant growth and finds application in the 
agricultural industry either directly or via plant growth promoting bacteria which were for example found in the rhizosphere from Stevia rebaudiana [2]. Indigo, the main coloring dye for denim, arises from oxidation of indole to indoxyl followed by oxidative dimerization [3].

In nature, the versatile widely distributed signaling molecule indole has significant roles in bacterial physiology, pathogenesis, animal behavior, and human diseases [4]. In bacteria, indole is known as intra- and intercellular signaling molecule that modulates diverse processes including plasmid stability, cell division, antibiotic tolerance, virulence, and spore formation $[4,5]$. Indole facilitates growth of plants, their root development or increased seedling growth, and functions in the response to herbivore attacks [4]. Animals cannot synthesize indole but can sense and modify indole. Indole is present in the gastrointestinal tract, the brain, or the blood of humans and might influence diseases such as cancers or bacterial infections [4,5]. In plants, indole-3-glycerol phosphate lyases (IGLs) cleave indole-3-glycerol to yield indole and D-glyceraldehyde-3-phosphate [6]. In bacteria, tryptophanases (TNAs) convert the amino acid L-tryptophan to indole, pyruvate, and ammonia [7].

Different physiological responses to extracellular addition or intracellular synthesis of indole have been described for indole-producing as well as for non-indole-producing bacteria affecting growth, biofilm formation, antibiotic resistance, acid and heat resistance, or indole persistence [5]. These effects may vary, e.g., biofilm formation is increased by indole in E. coli and Pseudomonas putida, but decreased in Paenibacillus alvei. Similarly, tolerance to antibiotics is decreased by indole in Staphylococcus aureus and Vibrio anguillarum, but increased in Agrobacterium tumefaciens and Vibrio cholera [5]. Thus, while indole often has profound effects on bacteria, it remains to be studied if these are detrimental or beneficial. Transport of indole across the bacterial cell membrane has been best studied in E. coli, where Mtr [8,9] and Mtr independent uptake of indole by diffusion [10] have been found. Export of indole may involve AcrEF [11].

Aerobic degradation of indole proceeds via the two key intermediates: isatin and anthranilate [12,13]. Several aromatic oxygenases, such as phenol hydroxylase and cytochrome P450 hydroxylase, can oxidize indole (at C2 or C3 position) to yield indoxyls, which are further oxidized to indigoids $[12,13]$. The first potential indole-specific hydrolases were recently identified in Acinetobacter [14] and Cupriavidus [15]. A gene cluster responsible for indole upstream metabolism to produce anthranilate was identified in both bacteria. Indole is degraded to anthranilate by the indole oxygenase with oxygenase and flavin reductase subunits, followed by a short-chain dehydrogenase and a cofactor independent oxygenase [14]. Indole degradation under anaerobic conditions occurs with tryptophan and isatin as key intermediates. The main difference between both conditions is the hydroxylation at the $\mathrm{C} 2$ position leading to 2-oxiindole [12,13].

The knowledge about the genetic mechanism underlying the physiological response in bacteria is limited. Most studies were focused on the visible changes in the physiological response on indole and only a few about the transcriptomic response [16,17]. C. glutamicum, which is used for the industrial production of amino acids including the aromatic amino acid L-tryptophan, does not synthesize indole, but is able to utilize a number of other aromatic compounds for growth [18-28]. The degradation pathways mainly share the two intermediates catechol and protocatechuate (PCA), which via $\beta$-ketadipate enter the central carbon metabolism as succinyl-CoA and acetyl-CoA $[18,29]$. This so-called $\beta$-ketoadipate pathway is widely distributed among bacteria and serves as main degradation pathway in C. glutamicum. The degradation of resorcinol and 2,4-dihydroxybenzoate also occurs via this pathway, using 1,2,4-trihydroxybenzene as intermediate [23,24,30]. In contrast, naphthalene is converted via gentisate to fumarate and pyruvate [19,31]. Transport systems [32-35], transcriptional regulators [36-41], and production of aromatic compounds [42-48] have been described for C. glutamicum. In order to test if indole is metabolized by C. glutamicum or exerts a regulatory role as a putative signaling molecule, we determined the physiological and transcriptomic response of C. glutamicum to indole. 


\section{Materials and Methods}

\subsection{Bacterial Strains and Molecular Genetic Techniques}

All bacterial strains used are listed in Table 1. E. coli DH5 $\alpha$ [49] was used for plasmid construction. C. glutamicum WT and $\mathrm{C}^{*}$ were used for investigation of indole response. Standard molecular genetic techniques were performed as described in [50]. Competent E. coli DH5 $\alpha$ [49] was performed with the $\mathrm{RbCl}$ method and transformed by heat shock [50]. Transformation of C. glutamicum was performed by electroporation [51].

Table 1. Bacterial strains used in this study.

\begin{tabular}{|c|c|c|}
\hline Strains & Description & Source \\
\hline \multicolumn{3}{|c|}{ Corynebacterium glutamicum } \\
\hline WT & C. glutamicum wild type ATCC13032 & ATCC \\
\hline $\mathrm{C} 1^{*}$ & Genome-reduced chassis strain derived from WT & {$[52]$} \\
\hline$\Delta d t x R$ & WT containing $d t x R$ deletion & [53] \\
\hline$\Delta \operatorname{ros} R$ & WT containing $\operatorname{ros} R$ deletion & [54] \\
\hline$\Delta \operatorname{cg} 3388$ & WT containing $\operatorname{cg} 3388 / i h t R$ deletion & [55] \\
\hline $\mathrm{C} 1^{*} \Delta d t x R$ & $C 1^{*}$ containing $d t x R$ deletion & This study \\
\hline $\mathrm{C} 1 * \Delta \operatorname{ros} R$ & $C 1^{*}$ containing $\operatorname{ros} R$ deletion & This study \\
\hline IVO20 & Strain evolved from WT after 20 transfers in the presence of indole & This study \\
\hline IVO38 & Strain evolved from WT after 38 transfers in the presence of indole & This study \\
\hline $\mathrm{C} 1 * \operatorname{cg} 3388^{\mathrm{M} 1 \mathrm{~T}}$ & $\mathrm{C}^{*}$ with SNP in $c g 3388 /$ iht $R$, resulting in amino acid exchange M1T & This study \\
\hline $\mathrm{C} 1 * w h c B^{\mathrm{R} 63 \mathrm{~L}}$ & $\mathrm{C} 1^{*}$ with SNP in $w h c B$, resulting in amino acid exchange R63L & This study \\
\hline $\mathrm{C} 1^{*} \operatorname{cg} 3388^{\mathrm{M} 1 \mathrm{~T}} \mathrm{dtxR} \mathrm{R}^{\mathrm{T} 8 \mathrm{~A}}$ & $\mathrm{C}^{*}$ with SNP in $c g 3388 / i h t R$ and $d t x R$, resulting in amino acid exchange M1T and T8A & This study \\
\hline $\mathrm{C} 1^{*} c g 3388^{\mathrm{M} 1 \mathrm{~T}} w h c B^{\mathrm{R} 63 \mathrm{~L}}$ & $\begin{array}{l}\mathrm{C} 1^{*} \text { with SNP in } c g 3388 / i h t R \text { and } w h c B \text {, resulting in amino acid exchanges M1T and } \\
\text { R63L, respectively }\end{array}$ & This study \\
\hline $\mathrm{C} 1^{*} c g 3388^{\mathrm{M} 1 \mathrm{~T}} \mathrm{dtxR^{ \textrm {T } 8 \mathrm { A } }} w h c B^{\mathrm{R} 63 \mathrm{~L}}$ & $\begin{array}{l}C 1^{*} \text { with SNPs in } c g 3388 / i h t R, d t x R \text { and } w h c B \text {, resulting in amino acid exchanges M1T, } \\
\text { T8A and R63L, respectively }\end{array}$ & This study \\
\hline $\mathrm{C} 1 *(\mathrm{pVWEx} 1)$ & $\mathrm{C} 1^{*}$ carrying $\mathrm{pVWEx} 1$ & This study \\
\hline $\mathrm{C} 1^{*}(\mathrm{pVWEx} 1-p h e)$ & $\mathrm{C} 1^{*}$ carrying pVWEx1-phe & This study \\
\hline $\mathrm{C} 1 * \Delta p h e(\mathrm{pVWEx} 1)$ & $C 1^{*}$ containing phe deletion, carrying pVWEx1 & This study \\
\hline $\mathrm{C} 1 * \Delta p h e(\mathrm{pVWEx1}-p h e)$ & $C 1^{*}$ containing phe deletion, carrying pVWEx1-phe & This study \\
\hline $\mathrm{C} 1 *(\mathrm{pEKEx} 3)$ & C $1^{*}$ carrying pEKEx3 & This study \\
\hline $\mathrm{C1}$ * (pEKEx3-cg2796-cg2797) & $\mathrm{C} 1^{*}$ carrying pEKEx3-cg2796-cg2797 & This study \\
\hline $\mathrm{C} 1^{*} \Delta c g 2796-c g 2797(\mathrm{pEKEx} 3)$ & $C 1^{*}$ containing $c g 2796-c g 2797$ deletion, carrying pEKEx3 & This study \\
\hline $\mathrm{C}^{*} \Delta \operatorname{cg} 2796-c g 2797$ (pEKEx3-cg2796-cg2797) & $\begin{array}{l}C 1^{*} \text { containing } \operatorname{cg} 2796-\operatorname{cg} 2797 \text { deletion, carrying pEKEx3-cg2796-cg2797 } \\
\text { Escherichia coli }\end{array}$ & This study \\
\hline S17-1 & recA pro $h s d R$ RP4-2-Tc::Mu-Km::Tn7 & [56] \\
\hline $\mathrm{DH} 5 \alpha$ & F-thi-1 endA1 hsdr17(r-, m-) supE44 1 lacU169 (Ф80lacZ1M15) recA1 gyrA96 & [49] \\
\hline BL21 (DE3) & $\begin{array}{c}\text { F-ompT gal dcm lon hsdSB(rB-mB-) } \lambda(\text { DE3[lacI lacUV5-T7p07 ind1 sam7 } \\
\operatorname{nin} 5])[m a l B+] K-12(\lambda S)\end{array}$ & [57] \\
\hline
\end{tabular}

Chromosomal gene deletions, replacements, and base exchanges in C. glutamicum were performed by two-step homologous recombination [51] using the suicide vector pK19mobsacB [58]. The genomic regions flanking the respective gene for homologous recombination were amplified from $C$. glutamicum as described elsewhere [50] using the respective primer pairs (Supplementary Data Table S1). The purified PCR products were assembled and simultaneously cloned into restricted pK19mobsacB by Gibson Assembly resulting in the plasmids listed in Supplementary Data Table S2. For construction of $19 m o b s a c B-\Delta d t x R$ and $\mathrm{pK} 19 m o b s a c B-\Delta \operatorname{ros} R$, the strains $\Delta d t x R$ and $\Delta \operatorname{ros} R$ were used as templates for fragment amplification by PCR. Transfer of the suicide vectors was carried out by transconjugation using E. coli S17 as donor strain [56]. For the first recombination event, integration of the vector in one of the targeted flanking regions was selected via kanamycin resistance. The resulting clones showed sucrose sensitivity due to levansucrase gene $s a c B$. Suicide vector excision was selected by sucrose resistance. Gene deletions or replacements were verified by PCR and sequencing with respective primers (Supplementary Data Table S1). Overexpression of genes with artificial optimized ribosomal binding sites (RBS) [59] in C. glutamicum $\mathrm{C}^{*}$ was performed with the C. glutamicum/E. coli shuttle vector $p V W E x 1$ or $p E K E x 3$. Protein expression for purification was done with the overexpression vector pET-16b (Novagen, Merck Group, Darmstadt, Germany). 


\subsection{Culture Conditions}

Precultures of E. coli and C. glutamicum were performed in lysogeny broth (LB) at 37 or $30^{\circ} \mathrm{C}$ in baffled shake flasks on a rotary shaker (160 or $120 \mathrm{rpm}$ ). Cultures were inoculated freshly from LB agar plates. When necessary, kanamycin $\left(25 \mu \mathrm{g} \mathrm{m} \mathrm{L}{ }^{-1}\right)$ or spectinomycin $\left(100 \mu \mathrm{g} \mathrm{m} \mathrm{L}^{-1}\right)$ were added to the medium. For induction of gene expression from vectors pVWEx1 or pEKEx3 $1 \mathrm{mM}$ isopropyl- $\beta$-D-1-thiogalactopyranoside (IPTG) was added to the medium. For growth or production experiments with C. glutamicum, precultures as described above were harvested (3200× g, $7 \mathrm{~min}$ ), cells were washed with TN-buffer pH $6.3(50 \mathrm{mM}$ Tris-HCL, $50 \mathrm{mM} \mathrm{NaCl})$ and inoculated to an optical density at $600 \mathrm{~nm}\left(\mathrm{OD}_{600}\right)$ of 1 in CGXII minimal medium [51] with $40 \mathrm{~g} \mathrm{~L}^{-1}$ glucose as sole carbon source if not otherwise noted. C. glutamicum was grown in $500 \mathrm{~mL}$ or $100 \mathrm{~mL}$ baffled shake flasks or in Micro-Flask microtiter plates (24-square deep-well polypropylene, $17 \times 17 \mathrm{~mm}$, depth $40 \mathrm{~mm}$, Applikon Biotechnology, Delft, The Netherlands) at $30^{\circ} \mathrm{C}$ and 120 or $220 \mathrm{rpm}$, followed by measuring $\mathrm{OD}_{600}$ using V-1200 spectrophotometer (VWR, Radnor, PA, USA) or microbioreactor system Biolector (m2p-labs; Aachen, Germany). For growth in the Biolector system, cultures were grown in LB-rich medium overnight and transferred to second preculture of CGXII minimal medium with $40 \mathrm{~g} \mathrm{~L}^{-1}$ glucose with addition of indole, if required until early exponential phase before inoculating to the main medium of CGXII minimal medium and $40 \mathrm{~g} \mathrm{~L}^{-1}$ glucose. Growth experiments in the Biolector system were carried out using 48-well flower plates (MTP-48-B; m2p-labs; Aachen, Germany) with a filling volume of $1 \mathrm{~mL}$, at $30^{\circ} \mathrm{C}$, and $1200 \mathrm{rpm}$ shaking frequency. Humidity was kept constant at $85 \%$, and online biomass measurements of scattered light were monitored with backscatter gain of 30 .

For mRNA isolation, C. glutamicum WT or C1* were cultivated in triplicates in CGXII minimal medium with $40 \mathrm{~g} \mathrm{~L}^{-1}$ glucose with addition of either \pm 2.5 or $\pm 4 \mathrm{mM}$ indole (Ind, dissolved in ethanol), $\pm 3 \mathrm{mM}$ indole-alanine TFA (Ind-Ala, dissolved in water), $\pm 2.5 \mathrm{mM}$ resorcinol (Res, dissolved in water), or $\pm 2.5 \mathrm{mM}$ myo-inositol (Ino, dissolved in water). Cultivation was performed in $100 \mathrm{~mL}$ baffled shake flasks at $220 \mathrm{rpm}$ at $30^{\circ} \mathrm{C}$ for all conditions. For the cultivation with $\pm 2.5 \mathrm{mM}$ indole, $500 \mathrm{~mL}$ baffled shake flaks were used. For transcription analysis by RNA sequencing, exponentially growing cells ( $\mathrm{OD}_{600}$ of 4 for $\pm 2.5 \mathrm{mM}$ indole, $\mathrm{OD}_{600}$ of 6 for the other conditions) were collected to $50 \mathrm{~mL}$ falcons filled with ice and centrifuged at $4{ }^{\circ} \mathrm{C}$ for $10 \mathrm{~min}$ at $3.220 \times \mathrm{g}$. For transcription analysis by qRT-PCR, $2 \mathrm{~mL}$ of culture was shortly spin down in precooled tubes at $4{ }^{\circ} \mathrm{C}$ at $3.220 \times \mathrm{g}$. The resulting cell pellets were frozen in liquid nitrogen and stored at $-80^{\circ} \mathrm{C}$ until further use. Growth was monitored in independent parallel cultures.

For adaptive laboratory evolution, C. glutamicum WT was cultivated in triplicates using $100 \mathrm{~mL}$ baffled shaking flasks at $120 \mathrm{rpm}$ and $30^{\circ} \mathrm{C}$ in CGXII minimal medium with $40 \mathrm{~g} \mathrm{~L}^{-1}$ glucose with different concentrations of indole (dissolved in ethanol). The culture reaching the highest $\mathrm{OD}_{600}$ after 24 or $72 \mathrm{~h}$ was harvested and washed with TN buffer and used to inoculate three new cultures. The indole concentration in the medium was increased when growth $\mathrm{OD}_{600}$ values were observed in the previous culture. In total, 38 transfers were done. Evolved strains were stored as glycerol culture at $-80^{\circ} \mathrm{C}$.

\subsection{Sequencing of Transcriptomis and Genomic Data}

\subsubsection{RNA Isolation, qRT-PCR, Preparation of cDNA Libraries for Sequencing and DeSeq Analysis}

In order to isolate total RNA from C. glutamicum cells, bacterial cell pellets previously harvested and kept at $-80{ }^{\circ} \mathrm{C}$ were thawed on ice and RNA was extracted individually for each cultivation condition using a NucleoSpin RNA isolation kit (Macherey-Nagel, Düren, Germany). Polymerase chain reactions with Taq polymerase (New England Biolabs, Frankfurt, Germany) were performed to detect if contaminating genomic DNA remained in the samples. RNA samples with genomic DNA contamination were treated with RNase-free DNase (Qiagen, Hilden, Germany). Total RNA concentrations were measured using a spectrophotometer (NanoDrop ${ }^{\circledR}$, ND-1000; ThermoFisher Scientific, Schwerte, Germany). RNA quality was checked by Trinean Xpose (Gentbrugge, Belgium) and Agilent RNA Nano 6000 kit on Agilent 2100 Bioanalyzer (Agilent Technologies, Böblingen, Germany). 
The extracted RNA samples were either pooled (treatment with indole) or separately treated (treatment with Ind-Ala). Ribo-Zero rRNA Removal Kit (Bacteria) from Illumina (San Diego, CA, USA) was used to remove the ribosomal RNA molecules from the isolated total RNA. Removal of rRNA was checked by Agilent RNA Pico 6000 kit on an Agilent 2100 Bioanalyzer (Agilent Technologies). RNA was free of detectable rRNA. Preparation of cDNA libraries were performed according to the manufacturer's instructions of the TruSeq stranded mRNA Kit (Illumina). Subsequently, each cDNA library was sequenced on a HiSeq1500 ( $2 \times 70$ nt PE rapid v2) Sequencer system (Illumina). The software Bowtie2 [60] was used for mapping to the respective genomes (BA000036 for WT, NZ_CP017995.1 for $\mathrm{C}^{*}$ ). In order to perform differential gene expression analysis, DEseq2 for separately treated samples and DEseq for pooled samples [61,62] were used as a part of the software ReadXplorer(2) [63,64]. Statistically significant expression changes (adjusted $p$-value $\leq 0.01$ ) with log 2 fold change $>1.5$ or $<-1.5$ were used. The transcriptomic data are available via NCBI GEO accession identifiers GSE159887 and GSE159888.

All qRT-PCRs were performed according to the manufacturer's instruction using the SensiFASTTM SYBR ${ }^{\circledR}$ No-ROX One-Step Kit (Meridian bioscience, Ohio, USA) and the CFX96 cycler system (Bio-Rad). The temperature profile was (1) $45^{\circ} \mathrm{C}$ for $10 \mathrm{~min}$ (reverse transcription); (2) $95^{\circ} \mathrm{C}$ for $2 \mathrm{~min}$; (3) 40 cycles of $95{ }^{\circ} \mathrm{C}$ for $5 \mathrm{~s}, 55^{\circ} \mathrm{C}$ for $10 \mathrm{~s}$, and $70{ }^{\circ} \mathrm{C}$ for $5 \mathrm{~s}$; (4) melt curve analysis with measures between 65 and $95^{\circ} \mathrm{C}$. The $\log 2$ fold change of the negative $\Delta \Delta \mathrm{Cq}$ (reference $\mathrm{Cq}$-sample $\mathrm{Cq}$ ) value, using the reference gene parA (cg3427), was used in calculations $[65,66]$. For each sample, three independent qRT-PCR experiments were performed.

\subsection{2. gDNA Isolation, Library Preparation and Sequencing}

For isolation of genomic DNA (gDNA), C. glutamicum WT and evolved strains were cultivated in triplicates in LB medium $100 \mathrm{~mL}$ baffled shake flasks at $120 \mathrm{rpm}$ and $30{ }^{\circ} \mathrm{C}$ overnight and the complete culture harvested. Genomic DNA was isolated using the NucleoSpin Microbial DNA kit for DNA, RNA, and protein purification (Macherey-Nagel) according to the manufacturer. Quality of isolated gDNA was analyzed using a spectrophotometer (NanoDrop ${ }^{\circledR}$, ND-1000). The complete digestion of the RNA was verified by gelelectrophoresis. Library preparation involved a TruSeq DNA PCR-free high-throughput library prep kit (Illumina) and Illumina genome sequencing was performed with a HiSeq1500 sequencer system $2 \times 250 \mathrm{nt}$ PE v2 HT (Illumina). The software snippy (https://github.com/tseemann/snippy) [67] was used for fast bacterial variant calling from NGS raw read data. The mapped data are available via BioProject: PRJNA669552. Detected SNPs in all triplicates were used for further analysis.

\subsection{Quantification of Amino Acids and Organic Acids by HPLC or GC-MS}

Extracellular amino acids and aromatic compounds were quantified by high-performance liquid chromatography (HPLC) (1200 series, Agilent Technologies Deutschland GmbH, Böblingen, Germany). The culture supernatants collected at different time points were centrifuged $(20,200 \times g)$ for HPLC analysis. Separation was performed with a precolumn (LiChrospher $100 \mathrm{RP} 18 \mathrm{EC}-5 \mu(40 \times 4 \mathrm{~mm})$, CS Chromatographie Service $\mathrm{GmbH}$, Langerwehe, Germany) and a main column (LiChrospher

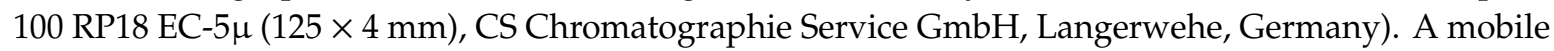
phase of buffer A ( $0.1 \%$ trifluoroacetic acid dissolved in water) and buffer B (acetonitrile) was used

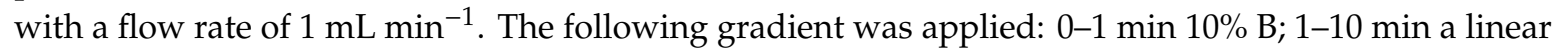
gradient of B from $10 \%$ to $70 \% ; 10-12 \mathrm{~min} 70 \% \mathrm{~B} ; 12-14 \mathrm{~min}$ a linear gradient of B from $70 \%$ to $10 \%$; 14-18 $\min 10 \%$ B [41]. The injection volume was $5 \mu \mathrm{L}$, and detection was performed with diode array detector at 210, 280, and $330 \mathrm{~nm}$.

For GC-MS analysis, supernatants of strains C1* (pVWEx1), C1* (pVWEx1-phe), and C1* (pEKEx3-cg2796-cg2797) were analyzed after growth without or in the presence of $2.5 \mathrm{mM}$ indole. Supernatants were collected after $16 \mathrm{~h}$ of cultivation and extracted with ethyl acetate. The ethyl acetate extract was washed three times with water to remove traces of CGXII medium components, followed by 
water removal using a Pasteur pipette plugged with silanized glass wool and $\mathrm{Na}_{2} \mathrm{SO}_{4}$. One microliter of each sample was injected into GC-MS. Samples were analyzed using a gas chromatograph (7890A, Agilent Technologies Deutschland) equipped with a $30 \mathrm{~m} \times 0.25 \mathrm{~mm} \times 0.25 \mu \mathrm{m}$ film thickness column (DB-5, Phenomenex). Helium was used as the carrier gas and the flow rate was adjusted to $1 \mathrm{~mL} \mathrm{~min}{ }^{-1}$ for GC-MS analysis. The injector was used in splitless mode and inlet temperature was set to $250^{\circ} \mathrm{C}$. The initial oven temperature was $45^{\circ} \mathrm{C}$ for $1 \mathrm{~min}$, and increased to $300{ }^{\circ} \mathrm{C}$ after $1 \mathrm{~min}$ at a rate of $10{ }^{\circ} \mathrm{C} \mathrm{min}-1$, which was held for $5 \mathrm{~min}$ at $300^{\circ} \mathrm{C}$. The GC was coupled to a Triple-Axis detector (5975C, Agilent Technologies Deutschland $\mathrm{GmbH})$.

\subsection{Protein Purification and Electrophoretic Mobility Shift Assay}

After transformation of the pET16b-cg3388 in E. coli BL21(DE3) transformants were grown at $37^{\circ} \mathrm{C}$ in $500 \mathrm{~mL}$ LB medium with $50 \mu \mathrm{g} \mathrm{mL}^{-1}$ ampicillin to an $\mathrm{OD}_{600}$ of 0.5 before adding IPTG $(0.5 \mathrm{mM})$ for induction of gene expression. After induction, cells were cultivated at $21^{\circ} \mathrm{C}$ for an additional $4 \mathrm{~h}$ and were harvested by centrifugation at $4{ }^{\circ} \mathrm{C}$. Pellets were stored at $-20^{\circ} \mathrm{C}$. Crude extract preparation and protein purification via Ni-NTA chromatography was performed as described elsewhere [68]. The purified regulator protein Cg3388 was used for EMSA experiments without removing the $\mathrm{N}$-terminal His-tag.

To analyze the physical protein-DNA interaction between the Cg3388 protein and their putative native target DNA, band shift assays were performed. The His-tagged Cg3388 protein was mixed in varying molar excess with $45 \mathrm{ng}$ of PCR amplified and purified intergenic fragment between start codon of cg3388 and cg3387 (429 bp, using oligonucleotides cg3388_EMSA_F and cg3388_EMSA_R) in band shift buffer (50 mM Tris- $\mathrm{HCl}, 4 \%(v / v)$ glycerol, $50 \mathrm{mM} \mathrm{KCl}, 10 \mathrm{mM} \mathrm{MgCl} 2,0.5 \mathrm{mM}$ EDTA, $\mathrm{pH}$ 7.5) in a total volume of $20 \mu \mathrm{L}$. The intergenic region was PCR-amplified and purified with NucleoSpin kit (MACHEREY-NAGEL GmbH \& Co. KG, Düren, Germany). A 78 bp-fragment of the upstream region of $c$ g2228 was added in every sample as a negative control using oligonucleotides cg2228_EMSA_F and cg2228_EMSA_R. BSA (bovine serum albumin) was used as negative control. After $30 \mathrm{~min}$ of incubation at room temperature, gel shift samples were separated on a native $7.5 \%(w / v)$ polyacrylamide. Additionally, the binding affinity in the presence of myo-inositol and different aromatic compounds 1,2,4-trihydroxybenzene, hydroquinone, 1,2-dihydroxybenzene, 1,3-dihydroxybenzene, 2,4-dihydroxybenzoic acid, 34-dihydroxybenzoic acid (protocatechuate), indole, 6-hydroxyindole, 5-hydroxyindole, L-tryptophan, and 5-hydroxy-L-tryptophan as effector was analyzed by incubation of the protein with the effector under buffered conditions for $15 \mathrm{~min}$ at room temperature prior to the addition of the intergenic DNA region. Subsequently, the gel shift samples were separated on $7.5 \%$ acrylamide retardation gel at $100 \mathrm{~V}$ buffered in $44.5 \mathrm{mM}$ Tris, $44.5 \mathrm{mM}$ boric acid and $1 \mathrm{mM}$ EDTA at $\mathrm{pH}$ 8.3. Staining of the DNA was achieved with ethidium bromide.

\subsection{Iron Reduction Assay}

The complex formation with the $\mathrm{Fe}^{2+}$-specific chelator bathophenanthroline disulfonic acid (BPS) was measured at $534 \mathrm{~nm}$ according to Müller et al. 2020 [69]. The kinetics of $\mathrm{Fe}^{3+}$ reduction was determined by an increase of absorbance. The iron reduction assay was performed in $25 \mathrm{mM}$ Tris-HCL buffer (pH 7.4), and $0.42 \mathrm{mM} \mathrm{FeCl}_{3}$ (final concentration) was added from a stock in $10 \mathrm{mM} \mathrm{HCl}$ neutralized with $50 \mathrm{mM} \mathrm{NaOH}$ immediately before use; $19.5 \mu \mathrm{M}$ PCA or indole was used. The reaction was started by the addition of $6.5 \mathrm{mM}$ BPS and measured every $30 \mathrm{~min}$. As control, reactions were measured without addition of PCA or indole.

\subsection{Pseudo-Dipeptid Synthesis}

For the synthesis of Indole-Ala-pseudo-Dipeptide, sodium hydride ( $60 \%$ suspension on paraffin oil, $0.1189 \mathrm{~g}, 2.96 \mathrm{mmol}, 1.2 \mathrm{eq}$ ) was suspended in ice cold N,N-dimethylformamid (DMF) (4 mL) and a solution of Indole (1, $0.2792 \mathrm{~g}, 2.38 \mathrm{mmol}, 1 \mathrm{eq})$ in DMF $(8 \mathrm{~mL})$ was added dropwise over $2 \mathrm{~min}$ and further stirred for $5 \mathrm{~min}$ at $0{ }^{\circ} \mathrm{C}$. Boc-Ala-OH $(2,0.8505 \mathrm{~g}, 4.64 \mathrm{mmol}, 1.9 \mathrm{eq})$ and 
2-(1H-Benzotriazole-1-yl)-1,1,3,3-tetramethylaminium tetrafluoroborate (TBTU) (1.5922 g, $4.96 \mathrm{mmol}$, 2.1 equivalents) were dissolved in dimethylformamide $(10 \mathrm{~mL})$, followed by the dropwise addition of 4-methylmorpholin (NMM) $(490 \mu \mathrm{L}, 4.38 \mathrm{mmol}, 1.8$ equivalents) and stirred for $40 \mathrm{~min}$ at ambient temperature. The Boc-Ala-OH solution was then added to the ice-cold sodium hydride suspension over a period of $2 \mathrm{~min}$. The ice bath was removed after $2.25 \mathrm{~h}$ and the reaction was further stirred for $1.3 \mathrm{~h}$ under ambient temperature. Afterwards the mixture was diluted with dichlormethane (DCM) $(50 \mathrm{~mL})$ and water $(100 \mathrm{~mL})$. The aqueous layer was extracted with DCM $(3 \times 50 \mathrm{~mL})$, the organic layers were combined and washed with water $(100 \mathrm{~mL})$, saturated $\mathrm{NaHCO}_{3}$-solution $(50 \mathrm{~mL})$, aqueous $\mathrm{HCl}$ $(1 \mathrm{M}, 50 \mathrm{~mL})$, water $(100 \mathrm{~mL})$ and saturated $\mathrm{NaCl}$-solution $(100 \mathrm{~mL})$. The organic phase was dried over $\mathrm{MgSO}_{4}$ and the solvent was removed under reduced pressure. The crude product was used for the further reaction without purification. Boc-cleavage was performed under acidic conditions and cooling. Thereafter the crude of protected pseudo-Dipeptide was dissolved in DCM (5 mL), cooled to $0{ }^{\circ} \mathrm{C}$ with an ice bath, and treated slowly with $\mathrm{HCl}$ ( $4 \mathrm{M}$ in dioxane, $4.6 \mathrm{~mL}, 1.9 \mathrm{eq})$. After $15 \mathrm{~min}$ the ice bath was removed, and the solution was stirred for $2.5 \mathrm{~h}$ at ambient temperature. Then the solvent was removed under reduced pressure, the residue was dissolved in water $(50 \mathrm{~mL})$ and DCM $(50 \mathrm{~mL})$. The aqueous layer was washed with DCM $(2 \times 50 \mathrm{~mL}, \mathrm{OP} 1)$, neutralized with sat. $\mathrm{NaHCO}_{3}$-solution $(50 \mathrm{~mL})$ and extracted with DCM $\left(3 \times 50 \mathrm{~mL}\right.$, OP2). OP2 was dried over $\mathrm{MgSO}_{4}$ and the solvent was removed under reduced pressure. The crude product was purified via reversed phase HPLC (water/ACN/0.1\% trifluoracetic acid (TFA)) to receive the desired Indole-Ala-pseudo-Dipeptide (4, $0.1468 \mathrm{~g}, 0.48 \mathrm{mmol}$, $20 \%$ ) as a colorless solid TFA-salt. The reaction mechanism and the ${ }^{1} \mathrm{H}-\mathrm{NMR}$ spectrum of the final product are shown in Supplementary Data Figure S1.

\section{Results}

\subsection{Growth and Global Gene Expression Response of C. glutamicum to Extracellularly Added Indole}

First, it was tested whether indole may serve as sole carbon or sole nitrogen source for growth of C. glutamicum strains WT and C1*. Indole $(2 \mathrm{mM})$ was used to replace either the carbon equivalent of glucose $(5.3 \mathrm{mM})$ or the nitrogen equivalent of the combined nitrogen sources urea and ammonium sulfate (0.7 and $1.31 \mathrm{mM}$, respectively). No growth was observed with indole as sole nitrogen or sole carbon source for $24 \mathrm{~h}$, but both strains grew when afterwards either $220 \mathrm{mM}$ glucose or $151 \mathrm{mM}$ $\left(\mathrm{NH}_{4}\right)_{2} \mathrm{SO}_{4}$ and $83 \mathrm{mM}$ urea were added (data not shown). Thus, indole does neither support growth of C. glutamicum as sole carbon or nitrogen source.

To determine the growth response of C. glutamicum strains WT and $\mathrm{C}^{*}$ to indole as additive to glucose minimal medium, different indole concentrations $(0 \mathrm{mM}$ to $8 \mathrm{mM})$ were added to the medium before inoculation and growth in a biolector cultivation was monitored (Figure 1A). At $6 \mathrm{mM}$ indole, for example, C. glutamicum WT showed a prolonged lag-phase, a growth rate decreased from $0.44 \pm 0.00$ to $0.14 \pm 0.03 \mathrm{~h}^{-1}$ and it did not reach the same biomass concentration as the control without indole addition (Figure 1A). Growth of the genome-reduced C. glutamicum chassis strain $\mathrm{C1}^{*}$ was also investigated since it grows as well as WT on glucose, but the response to indole was unknown (Figure 1B). Surprisingly, this strain showed a better growth performance in the presence of indole. For example, in the presence of $4 \mathrm{mM}$ indole, $\mathrm{C} 1^{*}$ grew faster than WT $\left(0.39 \pm 0.00 \mathrm{~h}^{-1}\right.$ as compared to $0.23 \pm 0.00 \mathrm{~h}^{-1}$ for $\mathrm{WT}$ ) and reached the same biomass concentration as the control without added indole (Figure 1B). The presence of $8 \mathrm{mM}$ indole affected growth of both strains severely (Figure 1). While in a colony-forming assay no colony-forming units were observed after exposure to $8 \mathrm{mM}$ indole for $1 \mathrm{~h}$ (Supplementary Data Figure S2), delayed growth in minimal media with $8 \mathrm{mM}$ indole was observed to some extent for C. glutamicum WT and, although slow, strain $\mathrm{C1}^{*}$ even grew to a comparable biomass concentration as without indole (Figure 1B). 
A

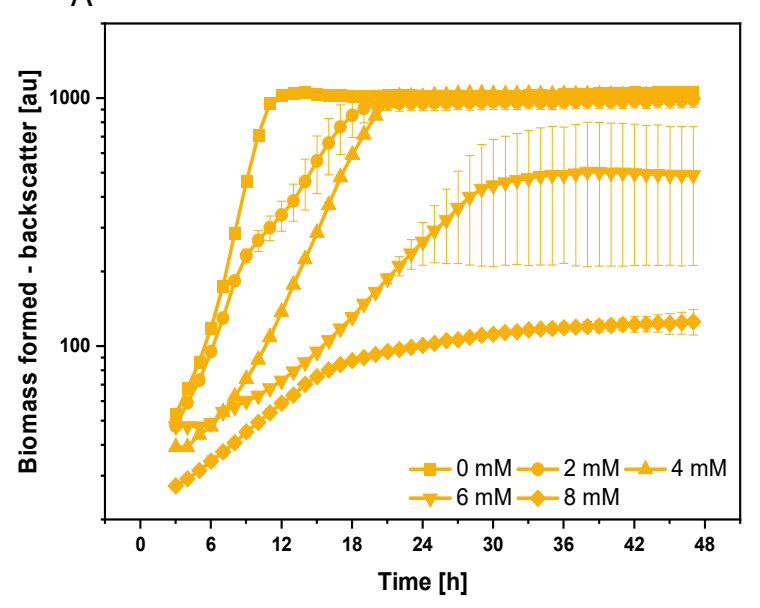

B

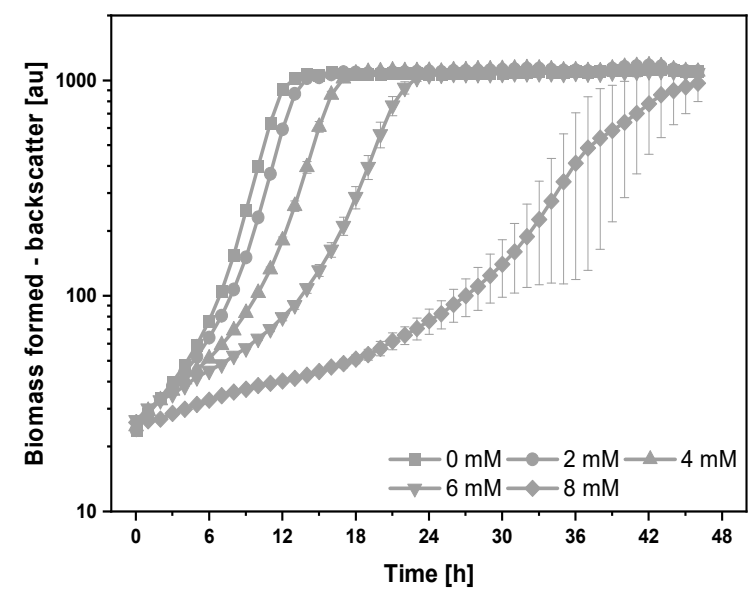

Figure 1. Growth of C. glutamicum WT (A) and $C 1^{*}(\mathbf{B})$ in the presence of extracellularly added indole. Cultivation with the indicated indole concentrations was performed in the biolector cultivation system. Means and standard deviations of triplicate cultivations are shown.

To determine the gene expression changes of $C$. glutamicum strains WT to extracellularly added indole, a differential gene expression analysis was performed (Table 2). RNA was isolated from cells growing exponentially in the absence or in the presence of $2.5 \mathrm{mM}$ indole. After confirmation of RNA integrity (RNA integrity number $>9$ ) and the absence of DNA contamination, the prepared RNA samples from biological triplicates were pooled and sequenced. A total of 3.36 million reads generated from isolated and sequenced mRNA were obtained. The trimmed reads (70 pb after processing) were mapped to the genome of $C$. glutamicum WT. In total, 35 genes showed significantly increased RNA levels (adjusted $p$-value $\leq 0.01$ ) in the presence of indole, while no gene showed decreased expression (Supplementary Data Figure S3A). Next, we chose a representative subset of genes for qRT-PCR analysis. As shown in Supplementary Data Figure S4A, qRT-PCR analysis of nine representative genes ( $c r e F, c y d B$, phe, $c g 0405$, irp1, porB, $c g 0591$, thiC, and qcrR) were performed. The pattern of differential gene expression determined in the RNAseq analysis was confirmed for all nine genes analyzed.

Among the genes that increased expression upon addition of $2.5 \mathrm{mM}$ indole were phenol 2-monooxygenase gene phe (cg2966), members of the DtxR regulon (e.g., cg2796-2797, dps, htaB, htaC, rip $A$ ), copper-related genes (e.g., $\operatorname{cop} B, \operatorname{copO}, c g 0464, c g 3402)$, and the operons for $p$-cresol catabolism and cytochrome bd (cydABCD) (Table 2). Since the $c y d A B C D$ operon and the operon for $p$-cresol catabolism are absent from $C$. glutamicum $\mathrm{C1}^{*}$, which cannot utilize $2 \mathrm{mM} p$-cresol as sole carbon source (Supplementary Data Table S3), these expression changes were not considered further. However, while the differentially expressed $c y d A B C D$ operon and the operon for $p$-cresol catabolism do not explain the effect of indole on growth of strain $\mathrm{C}^{*}$, they might be relevant for the observed strain differences between $\mathrm{WT}$ and $\mathrm{C} 1^{*}$ regarding indole. This finding may guide future experiments to better understand the strain differences with respect to the response to indole. In this study, we used the wild type and a genome-reduced strain derived from the wild type by a series of confirmed deletions and focused on the shared traits with respect to the indole response.

Since the largest expression changes were observed for phe and the two DtxR regulated genes $c g 2796$ and $c g 2797$ coding for unknown proteins, it was tested if their deletion or overexpression affected growth of C. glutamicum. However, growth in the presence of indole was comparable to that of the parent strain (Supplementary Data Figure S5). Analysis of culture supernatants of phe overexpression, deletion, and complementation strains, grown in presence and absence of $2 \mathrm{mM}$ indole, showed that indole concentrations decreased over time and could no longer be detected after $24 \mathrm{~h}$. Instead, the extracellular tryptophan concentration increased up to $1 \mathrm{mM}$ independent of the used strains, but only when indole was added. The $\operatorname{trp} A B$ encoded subunits of tryptophan synthase are believed to convert indole-3-glycerophospate to tryptophan without the release of indole. However, it is 
tempting to speculate that tryptophan synthase $\beta$ subunit may convert indole and serine to tryptophan. Neither HPLC analysis nor GC-MS analysis of the strains overexpressing phe or cg2796-cg2797 detected possible conversion products of indole (Supplementary Data Figure S6). Thus, neither overexpression nor deletion of phe, $c g 2796$, and cg2797 affected indole tolerance of C. glutamicum.

Table 2. List of genes differentially expressed in the presence of $2.5 \mathrm{mM}$ indole. C. glutamicum WT was cultivated in CGXII minimal medium with $40 \mathrm{~g} \mathrm{~L}^{-1}$ glucose in the presence of $2.5 \mathrm{mM}$ indole and cells were harvested during exponential growth $\left(\mathrm{OD}_{600} 4\right)$. Loci, genes, gene products, and Log2 fold changes of RNA levels are shown for genes with statistically significant expression changes (adjusted $p$-value $\leq 0.01$ ) with a $\log 2$ fold change $>1.5$ or $<-1.5$.

\begin{tabular}{|c|c|c|c|}
\hline Locus & Gene & Gene Product & Ind/- \\
\hline $\operatorname{cg} 0018$ & & uncharacterized membrane protein & 4.09 \\
\hline cg0405 & & ABC-type $\mathrm{Fe}^{3+}$-siderophore transport systems & 2.57 \\
\hline $\operatorname{cg} 0470$ & $h t a B$ & heme binding protein & 3.12 \\
\hline $\operatorname{cg} 0471$ & htaC & heme binding protein & 2.91 \\
\hline $\operatorname{cg} 0637$ & $\mathrm{creC}$ & benzylaldehyde dehydrogenases & 2.85 \\
\hline $\operatorname{cg} 0638$ & creD & phosphohydrolase & 3.11 \\
\hline $\operatorname{cg} 0639$ & creE & class I P450 system subunit & 3.59 \\
\hline $\operatorname{cg} 0640$ & creF & class I P450 system subunit & 3.81 \\
\hline $\operatorname{cg} 0641$ & creG & $\mathrm{NAD}^{+}$-dependent 4-hydroxybenzyl alcohol dehydrogenase & 3.01 \\
\hline $\operatorname{cg} 0642$ & $\mathrm{creH}$ & 4-methylbenzyl phosphate synthase subunit & 3.60 \\
\hline $\operatorname{cg} 0644$ & creI & 4-methylbenzyl phosphate synthase subunit & 3.95 \\
\hline cg0645 & creJ & class I P450 system subunit & 3.96 \\
\hline $\operatorname{cg} 1120$ & ripA & AraC-type DNA-binding domain-containing proteins & 2.47 \\
\hline $\operatorname{cg} 1152$ & $\operatorname{seu} B$ & acyl-CoA dehydrogenases & 3.20 \\
\hline $\operatorname{cg} 1298$ & $\operatorname{cydC}$ & ATP-binding/permease protein & 3.69 \\
\hline $\operatorname{cg} 1299$ & $c y d D$ & ATP-binding/permease protein & 3.77 \\
\hline $\operatorname{cg} 1300$ & $c y d B$ & cytochrome bd-type quinol oxidase, subunit 2 & 3.84 \\
\hline $\operatorname{cg} 1301$ & $c y d A$ & cytochrome bd-type quinol oxidase, subunit 1 & 3.72 \\
\hline $\operatorname{cg} 1773$ & ctaB & polyprenyltransferase & 2.45 \\
\hline $\operatorname{cg} 1881$ & & predicted iron-dependent peroxidase & 3.15 \\
\hline $\operatorname{cg} 1883$ & & uncharacterized secreted protein & 3.15 \\
\hline $\operatorname{cg} 1884$ & $\operatorname{cop} C$ & membrane-bound copper chaperone & 3.08 \\
\hline $\operatorname{cg} 1930$ & & hypothetical protein & 3.46 \\
\hline $\operatorname{cg} 1931$ & & hypothetical protein & 2.72 \\
\hline $\operatorname{cg} 2678$ & & ABC-type transporter. periplasmic component & 2.44 \\
\hline $\operatorname{cg} 2796$ & & uncharacterized protein involved in propionate catabolism & 6.87 \\
\hline $\operatorname{cg} 2797$ & & uncharacterized ACR & 6.29 \\
\hline $\operatorname{cg} 2962$ & & putative enzyme synthesing extracellular polysaccharides & 3.69 \\
\hline cg2966 & phe & putative phenol 2-monooxygenase & 6.14 \\
\hline $\operatorname{cg} 3280$ & & uncharacterized secreted protein & 2.70 \\
\hline $\operatorname{cg} 3281$ & $\operatorname{cop} B$ & cation transport ATPases & 2.67 \\
\hline $\operatorname{cg} 3286$ & & hypothetical protein & 3.09 \\
\hline $\operatorname{cg} 3287$ & $\operatorname{copO}$ & multicopper oxidase & 3.11 \\
\hline $\operatorname{cg} 3289$ & & thioredoxin-like protein & 3.82 \\
\hline $\operatorname{cg} 3327$ & $d p s$ & starvation-inducible DNA-binding protein & 4.40 \\
\hline
\end{tabular}

Differentially expressed copper- and iron-related genes prompted us to investigate the effect of different iron and copper ion concentrations in the growth medium on the growth response of C. glutamicum WT and $\mathrm{C} 1^{*}$ to indole (Figure 2A,B). Copper and iron concentrations exceeding the normal media concentrations $(1.25$ and $36 \mu \mathrm{M}$, respectively, s. dotted lines in Figure $2 \mathrm{~A}, \mathrm{~B})$ did not increase the maximal growth rate or the maximal biomass formation in the presence of $4 \mathrm{mM}$ indole. In addition, lowering of the medium copper and iron concentrations was not beneficial (Figure 2A,B). 
A

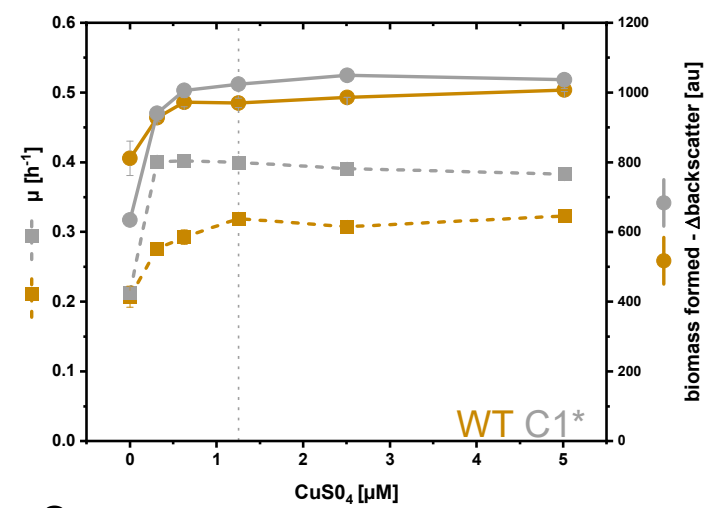

C

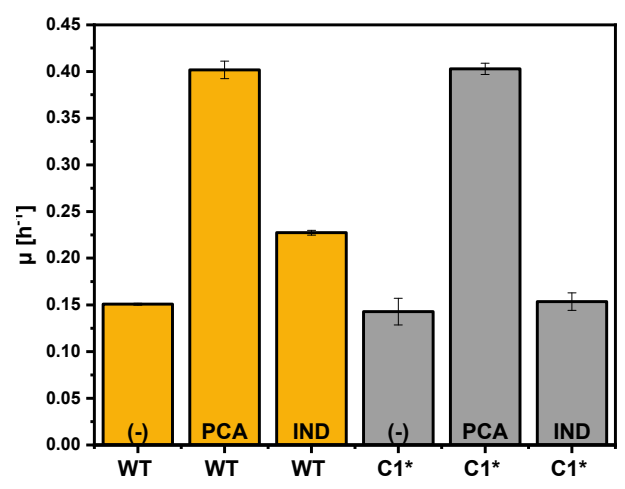

B

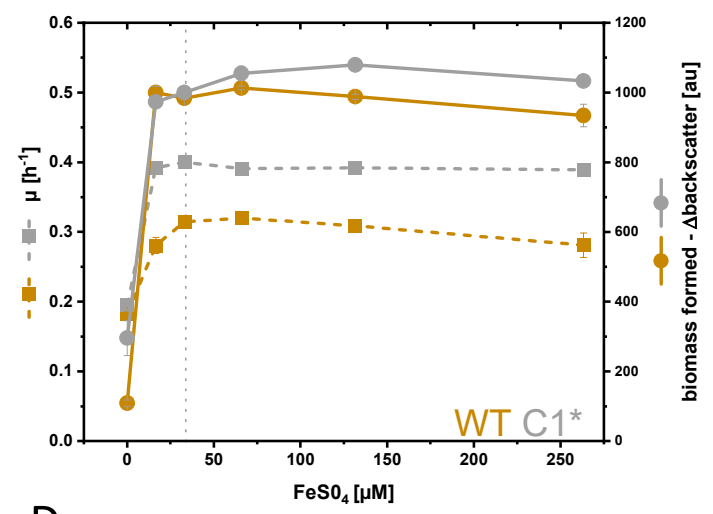

D

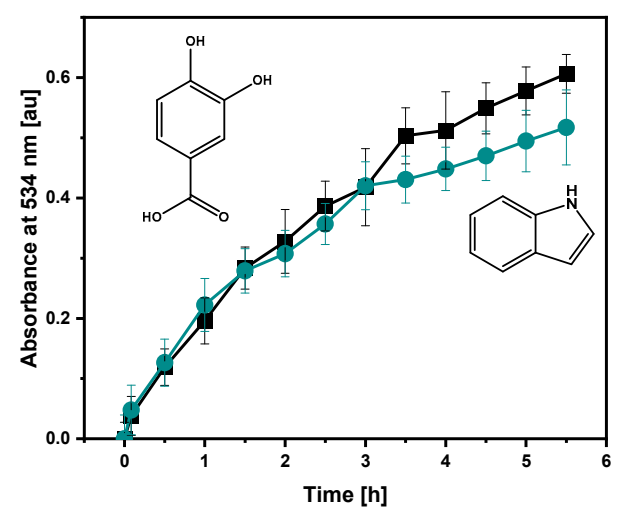

Figure 2. Growth of C. glutamicum WT (yellow) and $\mathrm{C}^{*}$ (gray) in the presence of varying $\mathrm{CuSO}_{4}$ (A) and $\mathrm{FeSO}_{4}$ (B) concentrations, with protocatechuate (PCA) or indole as iron chelators (C) and determination of iron reduction by indole and PCA as assayed with BPS (D). Maximal growth rates (dotted lines) and biomass concentrations ( $\Delta$ backscatter, filled lines) are depicted as means and standard deviations of duplicate cultivations (A,B). Maximal growth rates of cultivations of WT and $C 1^{*}$ without iron chelator (-) or with $195 \mu \mathrm{M}$ PCA or indole as iron chelator are given as means and standard deviations of triplicates cultivations. The kinetics of $\mathrm{Fe}^{3+}$ reduction (D) were monitored using BPS as described in Material and Methods. Means and standard deviations of triplicates are shown.

Next, indole was tested as replacement of the common iron chelator protocatechuate (PCA) (Figure 2C). Precultures grown in CGXII minimal medium with $40 \mathrm{~g} \mathrm{~L}^{-1}$ glucose without addition of an iron chelator like PCA were used to inoculate main cultures containing either $195 \mu \mathrm{M}$ PCA or $195 \mu \mathrm{M}$ indole as iron chelators. Albeit WT reached a maximal growth rate of $0.23 \pm 0.00 \mathrm{~h}^{-1}$ with indole, indole could not (fully) make up for PCA as an iron chelator that supported maximal growth rates of $0.40 \pm 0.01 \mathrm{~h}^{-1}$ for $\mathrm{WT}$ and $\mathrm{C}^{*}$. Based on the recent finding that PCA reduces $\mathrm{Fe}^{3+}$ to $\mathrm{Fe}^{2+}[69]$, a BPS-dependent iron reduction assay was performed. Surprisingly, $19.5 \mu \mathrm{M}$ indole reduced $\mathrm{Fe}^{3+}$ to $\mathrm{Fe}^{2+}$ in a similar manner as $19.5 \mu \mathrm{M}$ PCA (Figure 2D), while iron reduction was not observed without addition of indole or PCA. Thus, induction of iron-related genes by the extracellular addition of $2.5 \mathrm{mM}$ indole (Table 2) may be due to its ability to reduce $\mathrm{Fe}^{3+}$ to $\mathrm{Fe}^{2+}$.

\subsection{Transtriptome Analysis of C. glutamicum $\mathrm{C1}^{*}$ in Response to Indole-Alanine Dipeptide}

Since effects due to extracellularly added indole, e.g., due to reduction of medium $\mathrm{Fe}^{3+}$ to $\mathrm{Fe}^{2+}$ by indole (Figure 2D), may differ from increasing the intracellular indole concentration, a differential gene expression analysis was performed with C. glutamicum $\mathrm{C} 1^{*}$ grown in the absence or presence of $3 \mathrm{mM}$ of the dipeptide indole-alanine. Indole-alanine dipeptide was prepared from indole and tert-butyloxycarbonyl protected L-alanine (Supplementary Data Figure S1). It is known that C. glutamicum takes up dipeptides fast and hydrolyzes them efficiently to the amino acid monomers [70]. 
While alanine is readily catabolized, indole is expected to accumulate in the C. glutamicum cell in a similar way as shown, e.g., for arginine upon addition of arginine-alanine dipeptide [71]. However, we did not measure the intracellular indole concentration, thus, it is only expected that the intracellular indole concentration was actually increased. Total RNA was isolated from cells growing exponentially in the absence or presence of $3 \mathrm{mM}$ indole-alanine. In a parallel culture, no indole-alanine dipeptide could be detected by HPLC after $24 \mathrm{~h}$ cultivation, but $0.75 \mathrm{mM}$ tryptophan (Supplementary Data Figure S1). After confirmation of RNA integrity and absence of DNA contamination, the prepared RNA samples were sequenced in three biological replicates. The total number of reads generated from isolated and sequenced mRNA was 10.5 million. The reads were trimmed to $70 \mathrm{bp}$ before mapping to the genome of C. glutamicum $\mathrm{C}^{*}$. In total, 37 genes showed increased expression (log2 fold change of RNA level $\geq 1.5$; adjusted $p$-value $<0.01$ ) in the presence of indole-alanine, whereas 6 genes showed decreased expression ( $\log 2$ fold change of RNA level $\leq-1.5$; adjusted $p$-value $<0.01$; Table 3 ). The results obtained in the RNAseq analysis were validated by qRT-PCR for a subset of genes. The relative gene expression levels for four upregulated and four downregulated genes determined by qRT-PCR confirmed the pattern of their differential gene expression determined by RNAseq analysis (Supplementary Data Figure S4B).

Upon addition of indole-alanine, phe, cg3195, the gene coding for another monooxygenase, genes coding for citrate cycle and related enzymes ( $s u c C D$, ace $A$, aceB, $\operatorname{prpDBC1}$, prpDBC2), regulator genes (cg3303, znr and cg3127), and dps encoding a starvation-induced DNA protecting protein showed increased RNA levels (Table 3). Reduced expression in the presence of indole-alanine was observed for 3-deoxy-7-phosphoheptulonate synthase gene aroG, RNase P gene $r p$ A, undecaprenol kinase gene bacC, $c g 2719$ coding for a putative enterochelin esterase, and two genes for putative membrane proteins (cg2096, cg0286). A common hallmark in the response to extracellular indole and to an increased intracellular indole concentration due to feeding indole-alanine peptide was increased expression of a subset of six genes: cg0018 (coding for an uncharacterized membrane protein), cg0464 (coding for a putative copper ion transporting P-type ATPase), cg2962 (encoding a putative enzyme synthesizing extracellular polysaccharides), cg3402 (coding for a copper chaperone), phenol oxygenase gene phe, and DNA protection gene $d p s$ (compare Tables 2 and 3). This led us to the speculation that the response to indole may involve copper-dependent oxidation and transport processes.

\subsection{Adaptive Laboratory Evolution for Increasing Indole Tolerance}

When higher indole concentrations were added to the culture medium, growth of the replicates differed (see large error bars, e.g., for WT and $6 \mathrm{mM}$ indole in Figure 1A), which may indicate that growth accelerating mutations had occurred in one, but not all of the three replicates. This prompted us to isolate mutants with the ability of fast growth in the presence of indole and, therefore, an adaptive laboratory evolution (ALE) experiment was performed (Figure 3A). C. glutamicum WT cells were grown in the presence of indole for 38 serial transfers. After each serial transfer culture, a glycerol stock of the population was frozen and, in addition, a single colony was isolated on agar plates and frozen (named IVO20 to IVO38). The indole concentration added to fresh medium was stepwise increased (4 to $8 \mathrm{mM}$ ) in the serial transfers (Figure 3A). ALE strain IVO38 grew to an OD of 40 and was chosen for further analysis in addition to the intermediate ALE strain IVO20. In the presence of 4 to $10 \mathrm{mM}$, both ALE strains grew with higher growth rates to higher biomass concentrations than C. glutamicum WT (Figure 3B,C). Long lag phases were observed in the presence of 8 and $10 \mathrm{mM}$ indole (data not shown). The biomass formed by IVO20 in the presence of $7 \mathrm{mM}$ indole (Figure 3A) was low compared to that of IVO38 with $8 \mathrm{mM}$ indole (Figure 3A), while both strains formed comparable biomass with 6 and $8 \mathrm{mM}$ indole (Figure 3C). These data cannot be directly compared since the data in Figure 3A were taken from the ALE experiment, i.e., by inoculation by serial dilution, whereas the data shown in Figure $3 \mathrm{C}$ are from parallel growth experiments inoculated from defined precultures. 
Table 3. List of genes differentially expressed in the presence $3 \mathrm{mM}$ indole-alanine dipeptide. The C. glutamicum strain C1* was cultivated in CGXII minimal medium with $40 \mathrm{~g} \mathrm{~L}^{-1}$ glucose in presence $3 \mathrm{mM}$ indole-alanine; cells were harvested during exponential phase $\left(\mathrm{OD}_{600} 6\right)$. Loci, genes, gene products, and $\log 2$ fold changes of RNA levels are shown for genes with statistically significant expression changes (adjusted $p$-value $\leq 0.01$ ) in at least one comparison with a log2 fold change $>1.5$ or $<-1.5$.

\begin{tabular}{|c|c|c|c|}
\hline Locus & Gene & Gene Product & Ind-Ala/- \\
\hline $\operatorname{cg} 0012$ & $\operatorname{ssuR}$ & transcriptional activator of sulfonate(ester) utilization & 1.84 \\
\hline $\operatorname{cg} 0018$ & & uncharacterized membrane protein & 5.36 \\
\hline $\operatorname{cg} 0120$ & & putative hydrolase & 1.66 \\
\hline $\operatorname{cg} 0175$ & & putative secreted protein & 1.85 \\
\hline cg0192 & & hypothetical protein & 1.97 \\
\hline cg0286 & & putative membrane protein & -2.23 \\
\hline $\operatorname{cg} 0464$ & & putative $\mathrm{Cu}^{2+}$ transporting P-type ATPase & 1.59 \\
\hline $\operatorname{cg} 0569$ & & cation transporting ATPase & 2.05 \\
\hline $\operatorname{cg} 0759$ & $\operatorname{prpD2}$ & methylcitrate dehydratase, involved in propionate catabolism & 2.38 \\
\hline $\operatorname{cg} 0760$ & prpB2 & methylisocitrate lyase, involved in propionate metabolism & 2.53 \\
\hline $\operatorname{cg} 0762$ & $\operatorname{prpC2}$ & methylcitrate synthase, involved in propionate catabolism & 2.57 \\
\hline $\operatorname{cg} 0796$ & prpD1 & putative (2-methyl) citrate dehydratase & 1.65 \\
\hline $\operatorname{cg} 0797$ & prpB1 & putative (methyl)isocitrate lyase & 1.82 \\
\hline $\operatorname{cg} 0798$ & $\operatorname{prpC1}$ & putative (methyl)citrate synthase & 1.76 \\
\hline $\operatorname{cg} 1279$ & & putative secreted protein & 2.05 \\
\hline $\operatorname{cg} 1327$ & & putative transcriptional regulator, Crp-family & 1.53 \\
\hline $\operatorname{cg} 1328$ & & putative heavy-metal ion transporting P-type ATPase & 1.72 \\
\hline $\operatorname{cg} 1393$ & & putative acetyltransferase, GNAT family & 1.78 \\
\hline $\operatorname{cg} 1470$ & & hypothetical protein & 2.58 \\
\hline cg1471 & & hypothetical protein & 1.51 \\
\hline $\operatorname{cg} 1635$ & & putative membrane protein & 1.51 \\
\hline $\operatorname{cg} 1710$ & $b a c A$ & undecaprenol kinase & -1.77 \\
\hline cg2096 & & putative membrane protein & -1.59 \\
\hline $\operatorname{cg} 2391$ & aroG & 3-deoxy-7-phosphoheptulonate synthase & -1.54 \\
\hline cg2500 & & putative transcriptional regulator. ArsR-family & 1.59 \\
\hline $\operatorname{cg} 2559$ & aceb & malate synthase & 1.79 \\
\hline $\operatorname{cg} 2560$ & aceA & isocitrate lyase & 2.34 \\
\hline $\operatorname{cg} 2719$ & & putative enterochelin esterase & -1.6 \\
\hline $\operatorname{cg} 2836$ & sucD & succinate-CoA ligase (ADP-forming), alpha subunit & 2.06 \\
\hline $\operatorname{cg} 2837$ & sucC & succinate-CoA ligase (ADP-forming), beta subunit & 2.23 \\
\hline cg2962 & & putative enzyme synthesing extracellular polysaccharides & 2.12 \\
\hline cg2966 & phe & putative phenol 2-monooxygenase & 2.08 \\
\hline $\operatorname{cg} 3169$ & pck & phosphoenolpyruvate carboxykinase (GTP) & 2.00 \\
\hline $\operatorname{cg} 3195$ & & putative flavin-containing monooxygenase & 1.60 \\
\hline $\operatorname{cg} 3202$ & farR & transcriptional regulator. GntR-family & 1.88 \\
\hline $\operatorname{cg} 3226$ & & putative MFS-type L-lactate permease & 2.05 \\
\hline $\operatorname{cg} 3303$ & & putative PadR-family transcriptional regulator & 2.26 \\
\hline $\operatorname{cg} 3327$ & $d p s$ & starvation-inducible DNA-binding protein & 1.85 \\
\hline $\operatorname{cg} 3367$ & & ABC-type multidrug transport system, ATPase & 1.72 \\
\hline $\operatorname{cg} 3402$ & & copper chaperone & 2.03 \\
\hline $\operatorname{cg} 3431$ & $\operatorname{rnp} A$ & ribonuclease $\mathrm{P}$ & -1.70 \\
\hline $\operatorname{cg} 4019$ & & hypothetical protein & 3.57 \\
\hline $\operatorname{cg} 4028$ & & hypothetical protein & 2.05 \\
\hline
\end{tabular}

In order to identify possible mutations that caused improved growth of the ALE strains IVO20 and IVO38, their genomes were sequenced (Figure 4). As compared to the genome sequence of the parental C. glutamicum WT strain, ALE strain IVO20 possessed three nonsilent single-nucleotide polymorphisms (SNPs) and one insertion of 7 nucleotides (Table 4). The mutations led to a frameshift with premature stop codon (duplicate sequence of ACCGCAT at base 17 to 23) in 4-aminobutyrate aminotransferase gene gabT [72], to the amino acid exchanges $\mathrm{R} 63 \mathrm{~L}$ in $\mathrm{WhcB}$, a stationary phase repressor of the gene for thioredoxin reductase, which restores oxidized proteins [73] and T8A in the DNA-binding helix-turn-helix motif of the regulator of iron metabolism DtxR [74]. Furthermore, the mutation of the translational start codon (ATG to ACG resulting in amino acid exchange M1T) of $c g 3388$, which codes for a IclR-family transcriptional regulator, makes protein synthesis from this gene unlikely. 
A

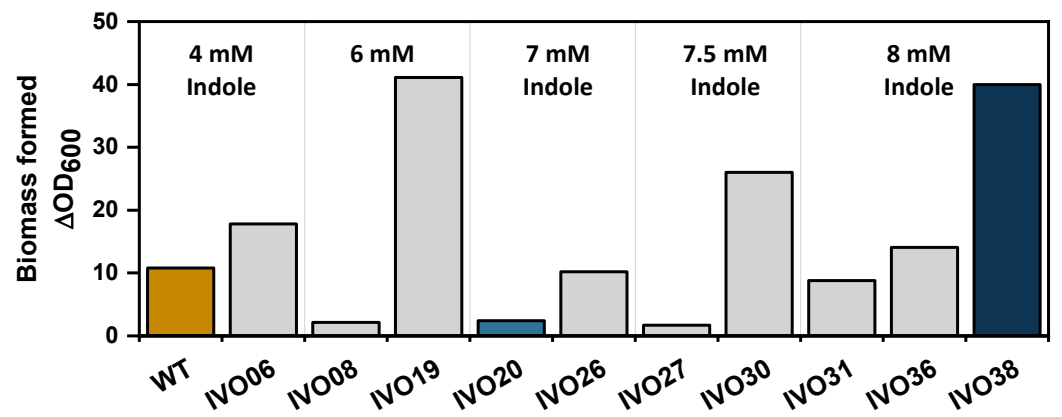

B

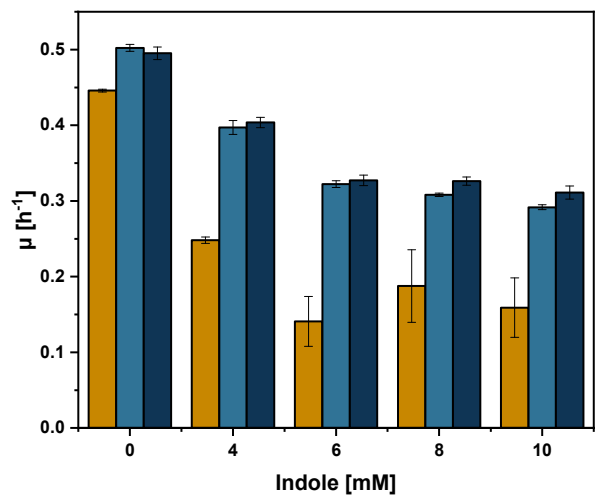

C

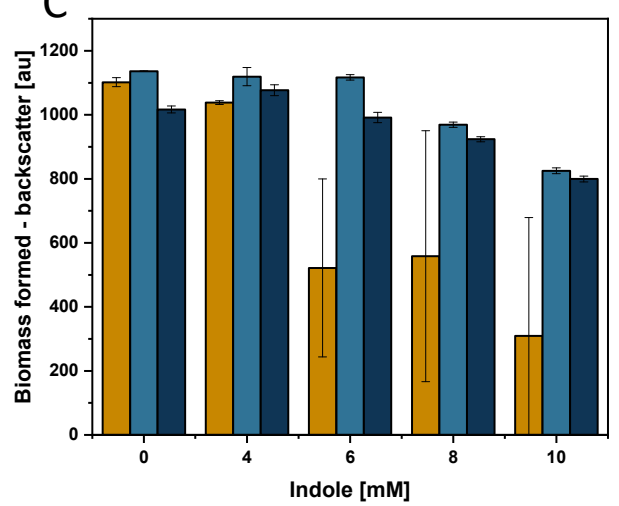

Figure 3. Adaptive laboratory evolution for fast growth in the presence of indole. The biomass formed after $24 \mathrm{~h}$ during the adaptive laboratory evolution at the indicated indole concentration is shown for selected transfers (A). Maximal growth rates (B) and biomass formation (C) of C. glutamicum WT (yellow), IVO20 (bright blue), and IVO38 (dark blue) with various indole concentrations shown as means and standard deviations of triplicate cultivations.
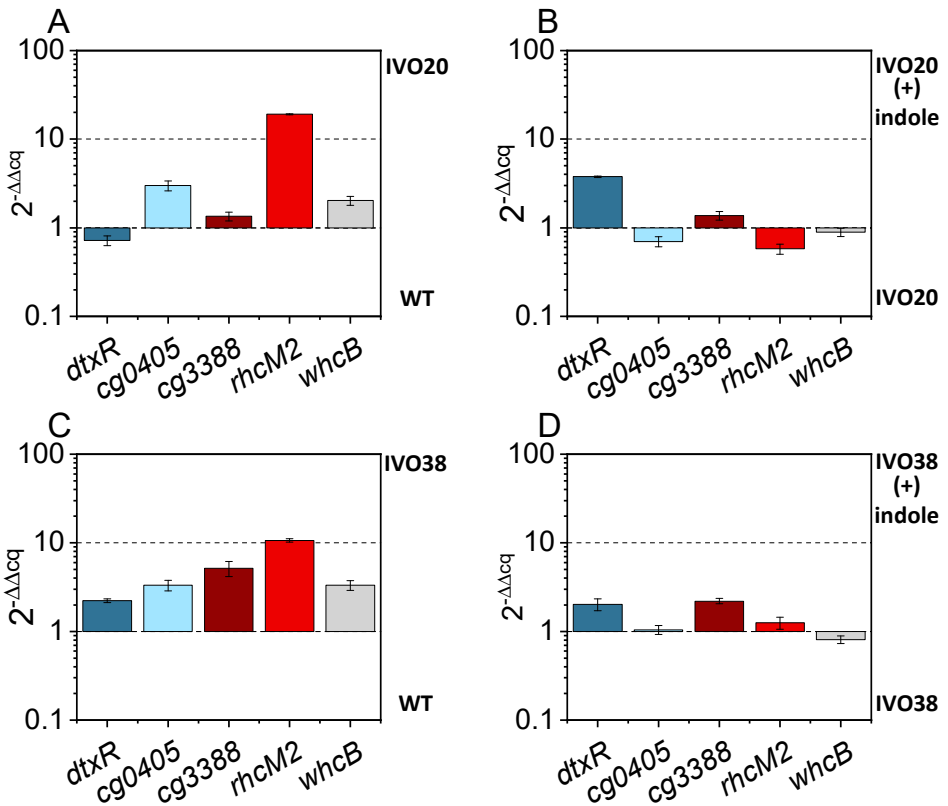

Figure 4. Results of qRT-PCR analysis for expression of $d t x R, c g 0405, c g 3388$, and $r h c M 2$ in the ALE strains IVO20 and IVO38 in the presence or absence of $4 \mathrm{mM}$ indole. Comparisons of IVO20 and WT in the absence of indole (A), IVO20 (+) indole vs. without indole (B), IVO38 and WT in the absence of indole (C), and IVO38 (+) indole vs. without indole (D). The log2 fold change of the $\Delta \Delta$ Cq value, using the reference gene parA is shown. Means and standard deviations of triplicate cultivations and independent performed qRT-PCRs are shown. 
Table 4. Single-nucleotide polymorphisms (SNPs) determined by whole-genome sequencing of ALE strains IVO20 and IVO38. Nonsilent SNPs and insertions found in the coding sequence of the strains IVO20 and IVO38 are given with the corresponding loci, gene names, gene products, and the resulting amino acid substitutions.

\begin{tabular}{|c|c|c|c|}
\hline Locus & Gene Name & Amino Acid Exchange & Gene Product \\
\hline $\operatorname{cg} 0695$ & whcB & R63L in IVO20 & Stationary phase repressor protein \\
\hline cg2103 & $d t x R$ & T8A in IVO20 & Transcriptional iron homeostasis repressor \\
\hline cg3388 & - & M1T in IVO20 & Putative transcriptional regulator. IclR-family \\
\hline $\operatorname{cg} 0566$ & $g a b T$ & $\begin{array}{c}\text { insertion in IVO20 } \\
\text { (ACCGCAT pos. } 17 \text { to } 23 \text { ) }\end{array}$ & 4-aminobutyrate aminotransferase \\
\hline $\operatorname{cg} 1324$ & $\operatorname{ros} R$ & T2I in IVO38 & Transcriptional regulator of oxidative stress response \\
\hline $\operatorname{cg} 1420$ & gatB & D452G in IVO38 & Glutamyl-tRNA (Gln) amidotransferase. subunit B \\
\hline $\operatorname{cg} 2103$ & $d t x R$ & $\mathrm{R} 103 \mathrm{H}$ in IVO38 & Transcriptional iron homeostasis repressor \\
\hline $\operatorname{cg} 3132$ & - & V310A in IVO38 & Putative membrane protein \\
\hline cg3388 & - & G69D in IVO38 & Putative transcriptional regulator. IclR-family \\
\hline
\end{tabular}

The genome of the ALE strain IVO38 showed an 82 kbp deletion ( $\triangle C G P 3 ;$ position 1776661-1986915), which was confirmed by PCR (Supplementary Data Figure S7). Excision of the prophage CGP3 is known to contribute to population heterogeneity in C. glutamicum [75]. Besides two synonymous mutations in cg1685 and the pyruvate kinase gene pyk [76] and one SNP in noncoding sequences, the genome of IVO38 contained five nonsilent SNPs in coding sequences (Table 4). Two SNPs altered the protein sequences of the aspartyl/glutamyl-tRNA ${ }^{(\mathrm{Asn} / \mathrm{Gln})}$ amidotransferase subunit B GatB (D452G) and putative membrane protein Cg3132 (G69D). Amino acid exchange T2I in the regulator of oxidative stress response RosR may not affect the function of the protein. However, the corresponding base change on the DNA level alters one of the two RosR binding sites (binding site rosRb $5^{\prime}$-TAGGTGATATGA $(\mathrm{C} \rightarrow \mathrm{T}) \mathrm{AACAC}-3^{\prime}$ ) affecting RosR autoregulation [54]. Two SNPs-affected genes mutated in IVO20 but led to different amino acid exchanges: R103H for DtxR and V310A for Cg3388. This argues that the single colony isolated from the grown population of the 20th transfer (IVO20) did not give rise to IVO38. (Note: transfers were done with aliquots of the grown culture, not with the single colonies isolated on agar plates from the grown cultures). Moreover, the finding of different mutations in their genes underscores the importance that DtxR and Cg3388 might have with respect to tolerance to indole.

In order to test if expression of $d t x R$ and $c g 3388$ and their (putative) regulatory targets $c g 0405$ and rhcM2 (cg3386), respectively, differs between C. glutamicum WT and the ALE strains IVO20 and IVO38, a qRT-PCR analysis was performed with RNA isolated from cells growing exponentially in the presence or absence of $4 \mathrm{mM}$ indole (Figure 4). The RNA level of $d t x R$ was higher in IVO38 than in WT (Figure 4C) and was increased in the presence of indole in IVO20 and IVO38 (Figure 4B,D). Expression of $c g 0405$, which is repressed by DtxR, was comparable in the absence and presence of indole, but was higher in the ALE strains IVO20 and IVO38 than in C. glutamicum WT (Figure 4A,C). This may indicate derepression of $c g 0405$ as consequence of the amino acid exchanges T8A and R103H found in DtxR in the ALE strains IVO20 and IVO38, respectively. Cg3388 has not been characterized to date, but was shown here (s. below) to regulate the divergently transcribed operon iolT2- rhcM2D2.

The cg3388 RNA level was comparable in WT and IVO20, in which likely no Cg3388 protein is synthesized due to the SNP mutation of the translational start codon. However, in IVO38 (with SNP leading to $\mathrm{Cg} 3388^{\mathrm{G} 69 \mathrm{D}}$ ) expression of $\operatorname{cg} 3388$ was higher than in WT (Figure 4C), and was further increased in the presence of indole (Figure 4D). More rhcM2 RNA was found in IVO20 and IVO30 than in WT (Figure 4A,C), but indole did not further increase the rhcM2 RNA level in the ALE strains (Figure 4B,D). This may be explained by derepression of rhcM2 (and, possibly, the whole iolt2rhcM2D2 operon) due to absent or nonfunctional Cg3388. Reverse engineering revealed a major role of $\mathrm{Cg} 3388^{\mathrm{M} 1 \mathrm{~T}}$ in indole tolerance

In order to test which mutations are causal for increased tolerance to indole, a number of mutants were constructed and characterized. As SNPs were detected for DtxR and RosR (Table 4) and members of their regulons were differentially expressed upon addition of indole and/or the 
dipeptide indole-alanine (Tables 2 and 3), growth of the deletion strains $\mathrm{WT}, \Delta d t x R, \Delta \operatorname{ros} R, \mathrm{C}^{*}$, $C 1^{*} \Delta d t x R$, and $C 1^{*} \Delta r o s R$ was analyzed in the absence or presence of indole. In the presence of indole, faster growth was observed for strain $d t x R(0.36 \pm 0.00)$ and $\operatorname{ros} R(0.31 \pm 0.00)$ as compared to the wild type $(0.23 \pm 0.02)$, while growth in the absence of indole was comparable (Figure $5 \mathrm{~A}, \mathrm{~B})$. By contrast, deletion of neither $d t x R$ nor ros $R$ in $C 1^{*}$ improved growth in the presence of indole (Figure $5 \mathrm{~A}, \mathrm{~B}$ ). The deletion of $d t x R$ in $C 1^{*}$ even reduced the growth rate independent of the presence or absence of indole. Thus, neither $d t x R$ nor $\operatorname{ros} R$ mutations can explain the improved tolerance to indole observed in the ALE strains IVO20 and IVO38.
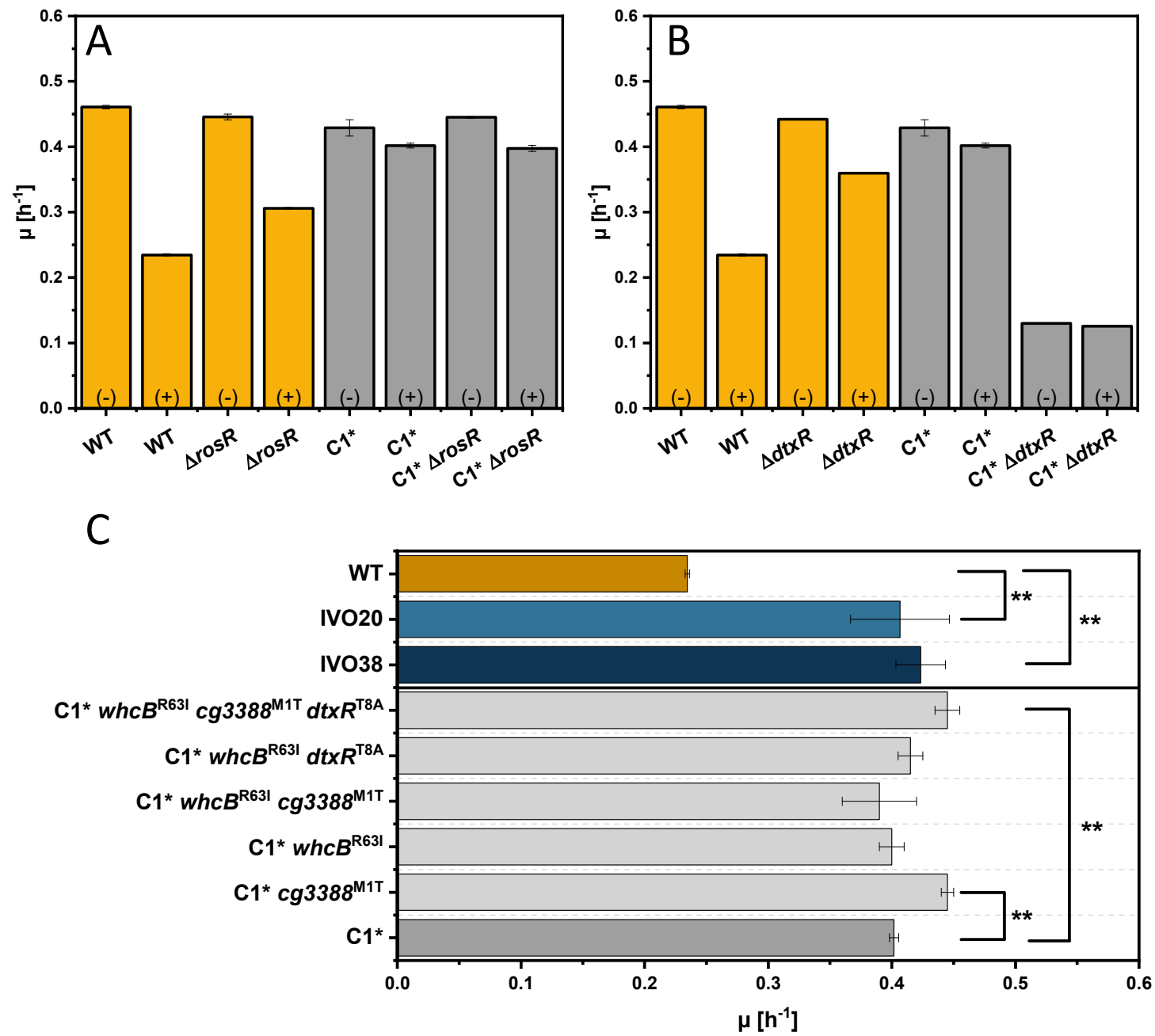

Figure 5. Growth comparison of $d t x R(\mathbf{A})$ and $r o s R$ deletion strains (B) and reverse engineered strains (C) in presence of indole. Maximal growth rates of rosR deletions strains (A) and $d t x R$ deletion strains (B) in absence (-) or presence of $4 \mathrm{mM}$ indole (+) and of reverse engineered strains in the presence of $4 \mathrm{mM}$ indole are shown as means and standard deviations of minimum of triplicates. Significance was determined based on a two-sided unpaired Student's t-test $\left.{ }^{* *}: p<0.05\right)$.

Next, the three SNPs detected in IVO20 were transferred to $\mathrm{C} 1^{*}$, which lacks all prophages including CGP3 that also was absent from IVO38. Growth of C. glutamicum WT, the ALE strains IVO20 and IVO38, as well as of $\mathrm{C}^{*}$ and the derived strains $\mathrm{C}^{*} c g 3388^{\mathrm{M} 1 \mathrm{~T}}, \mathrm{C}^{*} w h c B^{\mathrm{R} 63 \mathrm{~L}}, \mathrm{C}^{*} c g 3388^{\mathrm{M} 1 \mathrm{~T}}$ whc $B^{\mathrm{R} 63 \mathrm{~L}}$, $\mathrm{C} 1{ }^{*} \mathrm{dt} \times \mathrm{R}^{\mathrm{T} 8 \mathrm{~A}} w h c B^{\mathrm{R} 63 \mathrm{~L}}$, and $\mathrm{C}^{*} c g 3388^{\mathrm{M} 1 \mathrm{~T}} \mathrm{dt} \times \mathrm{R}^{\mathrm{T} 8 \mathrm{~A}} w h c B^{\mathrm{R} 63 \mathrm{~L}}$ was compared in the presence of $4 \mathrm{mM}$ indole (Figure 5C). Among the $\mathrm{C} 1^{*}$ derived strains growth with indole was significantly faster for strains $\mathrm{C}^{*} c g 3388^{\mathrm{M} 1 \mathrm{~T}}$ and $\mathrm{C} 1 * c g 3388^{\mathrm{M} 1 \mathrm{~T}} \mathrm{dt} \times \mathrm{R}^{\mathrm{T} 8 \mathrm{~A}}$ whc $B^{\mathrm{R} 63 \mathrm{~L}}$ (Figure $5 \mathrm{C}$ ). Thus, $\mathrm{Cg} 3388^{\mathrm{M} 1 \mathrm{~T}}$ plays a major role in indole tolerance. 


\subsection{Investigation of the Transcriptional Regulator Cg3388}

Two SNPs in cg3388 leading to amino acid changes were found: M1T and G69D. The SNP in the translational start codon (M1T) may result in the complete absence of Cg3388 protein, while the effect of the amino acid change G69D is not known. Therefore, we deliberately chose to delete $\operatorname{cg} 3388$ as we consider this the most clear cut genetic modification. Strain $\Delta c g 3388$ was constructed to test if deletion of $c g 3388$ improves indole tolerance in a similar manner as $c g 3388^{\mathrm{M} 1 \mathrm{~T}}$. Indeed, in the presence of indole the $c g 3388$ deletion mutant grew faster than WT $\left(0.47 \pm 0.00\right.$ vs. $\left.0.23 \pm 0.00 \mathrm{~h}^{-1}\right)$, which was comparable to the growth rate observed with $\mathrm{C} 1{ }^{*} \mathrm{cg} 3388^{\mathrm{M} 1 \mathrm{~T}}\left(0.45 \pm 0.00 \mathrm{~h}^{-1}\right.$; Figure 6A). This result corroborated the finding that Cg3388 plays a major role in the response of C. glutamicum to indole.

Due to similarities to other IclR-type transcriptional regulators that regulate adjacent, divergently transcribed operons, we tested if Cg3388 regulates the divergently transcribed operon iolT2-rhcM2D2. A qRT-PCR analysis of WT and $\Delta c g 3388$ grown without or with $2.5 \mathrm{mM}$ indole revealed increased RNA levels of $r h c M 2$. This finding is commensurate with a role of Cg3388 as repressor of $r h c M 2$ and, by inference, likely the iolT2-rhcM2D2 operon. UniProtKB analysis predicts an N-terminal helix-turn-helix DNA binding domain (HTH iclR-type) at position 20-81 and a C-terminal effector binding domain (IclR-ED) at position 82-266 for Cg3388 (Q8NL89), a domain structure typical for repressor proteins. As $r h c M 2$ and $r h c D 2$ codes for maleylacetate reductase and catechol 1,2-dioxygenase enzymes involved in resorcinol catabolism [23] and as IolT2 imports inositol into the C. glutamicum cell [77], the effect of addition of resorcinol and inositol was tested, but RNA levels of $c g 3388$ and rhcM2 were comparable to indole addition (Figure 6B).

In addition, the effect of $c g 3388$ deletion on the gene expression of phe and $c r e F$, which showed increased RNA levels under conditions with external and/or internal added indole, was analyzed. While phe RNA levels were not affected by deletion of $c g 3388$, creF showed increased RNA levels in the absence of Cg3388.

In order to test if $\mathrm{Cg} 3388$ protein physically interacts with target promoter DNA, an electrophoretic mobility shift assay (EMSA) was performed (Figure 6C). Purified His-tagged Cg3388 protein was incubated with the PCR amplified intergenic DNA region between the start codons of $c g 3388$ and iolT2. A band shift was observed with His-tagged Cg3388 protein, but not with BSA used as negative control protein. Thus, Cg3388 binds to the intergenic region between its own gene and the iolT2rhcM2D2 operon.

For identification of effectors of $\mathrm{Cg} 3388$, different compounds were added during the incubation of His-tagged Cg3388 protein with target DNA. The binding of Cg3388 to target DNA was hardly affected by the addition of $5 \mathrm{mM}$ of inositol, resorcinol (1,3-dihydroxybenzene), 1,2-dihydroxybenzene, 2,4-hydroxybencoic acid, PCA (3,4-dihydroxybenzoic acid), 6-hydroxyindole, 5-hydroxyindole, L-tryptophan, and 5-hydroxy-L-tryptophan (data not shown). By contrast, 1,2,4-trihydroxybenzene, hydroquinone (1,4-dihydroxybenzene), and indole interfered with binding of Cg3388 to its target DNA at concentrations exceeding $0.05,0.5$, and $4 \mathrm{mM}$, respectively (Figure 6C). Thus, Cg3388 responds to 1,2,4-trihydroxybenzene, hydroquinone, and indole as effector molecules that may function as inducers of $c g 3388$ and the iolT2-rhcM2D2 operon. Cg3388 was named IhtR for 1,2,4-trihydroxybenzene, hydroquinone, and indole responsive repressor. Since 1,2,4-trihydroxybenzene affected DNA binding of Cg3388 at the lowest concentration $(0.05 \mathrm{mM})$ and as maleylacetate reductase RolM and catechol 1,2-dioxygenase RolD are homologs of RhcD2 and RhcM2 converting 1,2,4-trihydroxybenzene to $\beta$-ketoadipate, 1,2,4-trihydroxybenzene is most likely the main physiological effector of Cg3388/IhtR. However, since hydroquinone and indole affected $\mathrm{Cg} 3388 / \mathrm{IhtR}$ in vitro at physiologically relevant concentrations they may also play a role in C. glutamicum in vivo. 
A

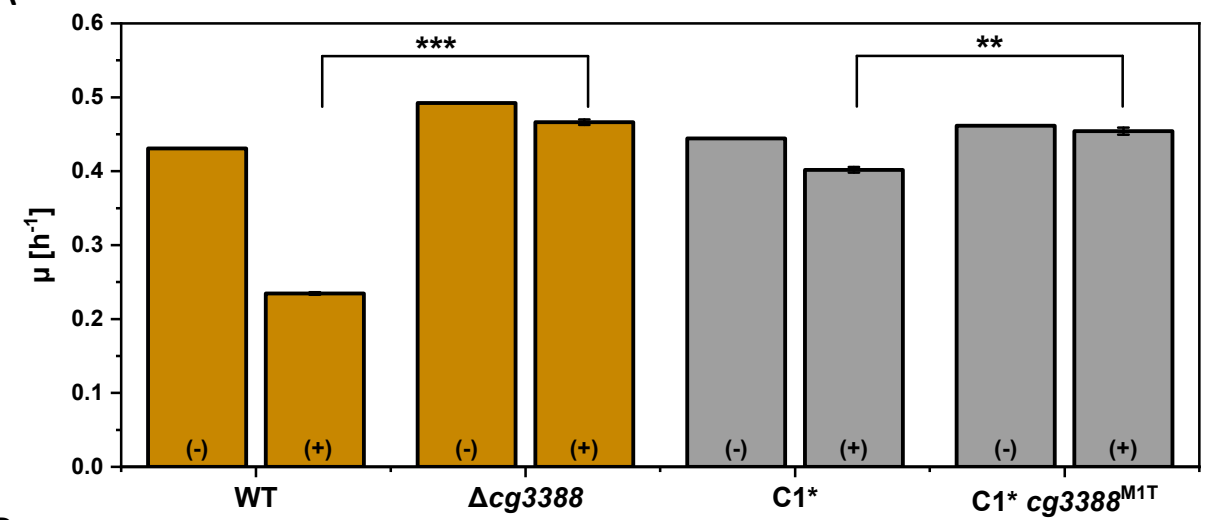

B
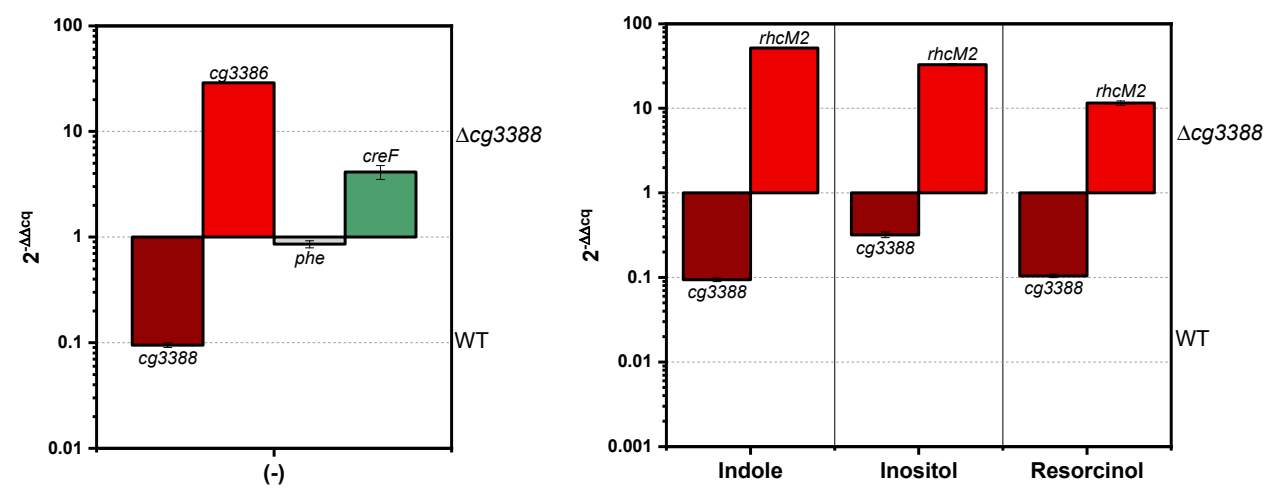

C

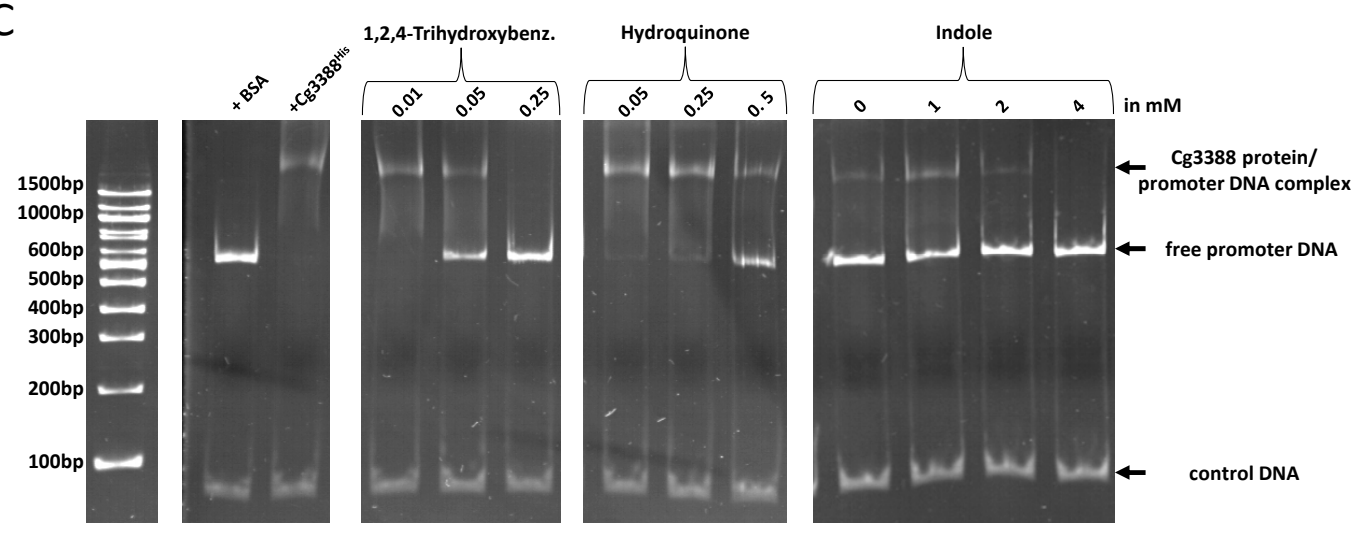

Figure 6. Indole-dependent effect on Cg3388. (A) Growth rates of strains WT, $\triangle c g 3388, C 1^{*}$, and $C 1^{*}$ $c g 3388^{\mathrm{M} 1 \mathrm{~T}}$ in CGXII minimal medium with $40 \mathrm{~g} \mathrm{~L}^{-1}$ glucose as carbon source in absence (-) and presence of $4 \mathrm{mM}$ indole $(+)$ are given as means and experimental imprecision of duplicates. Significance was determined based on a two-sided unpaired Student's t-test $\left.{ }^{* * *}: p<0.05\right)$; ${ }^{* * *} p<0.01$ ). (B) qRT-PCR analysis of WT and WT $\Delta c g 3388$ cells grown in presence of $2.5 \mathrm{mM}$ indole, inositol, or resorcinol is shown for $c g 3388$ (dark red), rhcM2 (light red), phe (gray), and creF (green) as means and standard deviations of triplicate cultivations. (C) Electrophoretic mobility shift assays (EMSA) with His-tagged Cg3388 (153 fold molar excess) and the intergenic region ( $45 \mathrm{ng}$ ) between cg3388 and iolT2 with addition of 1,2,4-trihydroxybenzene (0.01-0.025 mM), hydroquinone (0.05-0.05 mM), or indole (1-4 mM) are shown.

\section{Discussion}

The response of $C$. glutamicum to indole, which was shown to reduce $\mathrm{Fe}^{3+}$ to $\mathrm{Fe}^{2+}$ in the culture medium, is governed by increased expression of iron and copper metabolism genes, of phenol 2-monooxygenase gene $p h e$, and the $p$-cresol catabolic cre operon. Deletion of genes encoding the 
regulator of oxidative stress response RosR, the iron response regulator DtxR, and Cg3388/IhtR improved indole tolerance.

Extracellular indole affected expression of genes of iron homeostasis as it reduced $\mathrm{Fe}^{3+}$ to $\mathrm{Fe}^{2+}$ (Figure 2D) and deletion of the iron homeostasis repressor $d t x R$ improved growth in the presence of indole (Figure 5A). ALE strain IVO38 lacked prophage CGP3 and possessed a point mutation in $d t x R$ (Table 4). Excision of CGP3 is known to be prevalent in $d t x R$ mutants, possibly triggered by DNA damages caused by elevated intracellular iron concentrations [75]. The fact that $d t x R$ is not autoregulated nor known to be regulated by other transcriptional regulators [78] may explain that $d t x R$ mutations occur relatively often. Thus, improved indole tolerance of C. glutamicum required upregulation of DtxR targets that include intracellular iron storage proteins, high-affinity iron uptake systems, redox-stress resistance systems, and iron-containing proteins $[53,78]$. Growth in the presence of indole, however, was not improved by increasing the iron concentration in the culture medium (Figure 2B). Uptake of copper ions depends on iron-containing proteins as it is proposed that copper ions are either transported with the help of $\mathrm{Cg} 1883$ and $\mathrm{Cg} 0520$ to the cytochrome complex and/or with the help of CopC and CtiP, CopC and Cg1883 [74,79,80]. This may explain that indole also triggered the copper starvation response (increased RNA levels of $\operatorname{copO}, \operatorname{cop} B$, and $\operatorname{cop} C$ ) in addition to the DtxR regulon (e.g., cytochrome $b d$ genes $c y d A B C D$ ). Notably, when the intracellular indole concentration was increased by feeding the dipeptide indole-alanine, only two genes (dps and cg0405) of the DtxR regulon were induced (Table 3). Apparently, the presence of indole in the growth medium is required to trigger the DtxR regulon, likely by chemical reduction $\mathrm{Fe}^{3+}$ to $\mathrm{Fe}^{2+}$ by indole.

The response to the addition of the aromatic compound indole elicited increased expression of genes belonging to three pathways: phenol 2-monooxygenase (phe), the cre operon for catabolism of $p$-cresol, and the transcriptional regulator Cg3388/IhtR. Strain C1* lacks the cre operon and cannot use cresol as sole carbon source (Supplementary Data Table S3). Notably, as strain C1* possesses intact copies of $d t x R, \operatorname{ros} R$, and $c g 3388$, the absence of the cre operon may contribute to the higher indole tolerance of $C 1^{*}$ as compared to WT. In addition, or alternatively, the absence of CGP3 and the $c y d A B C D$ cluster from $\mathrm{C} 1^{*}$ may explain this strain difference. Cresol degradation is initiated by phosphorylation of the hydroxyl group catalyzed by 4-methylbenzyl phosphate synthase $[25,26]$. However, indole does not carry a hydroxyl group and has a heterocyclic structure consisting of one benzene ring and one pyrrole ring. This led us to speculate that indole elicits increased expression of the cre operon as it may be similar to the unknown inducer of this operon. On the other hand, we observed increased creF RNA levels upon deletion of $c g 3388$ (Figure 6B). Thus, Cg3388/IhtR may be involved directly or indirectly in the regulation of the cre operon. If $\mathrm{C} 1^{*}$ grows faster in the presence of indole because induction of the cre operon results in a metabolic burden or if an enzyme encoded by the cre operon converts indole to a more toxic compound remains to be studied. The latter may be less likely since we did not find indole degradation products in the supernatants (Supplementary Data Figure S6).

Phe encodes phenol 2-monooxygenase, which oxidizes phenol to catechol in an NADPH-dependent manner [81,82]. While it is known that the transcriptional AraC-type regulator PheR activates phe expression in the presence of phenol, phe is not expressed in the presence of glucose or absence of PheR [75,76]. Notably, phe expression increased upon addition of indole extracellularly as well as due to increased intracellular levels upon feeding indole-alanine dipeptide (Table 3 and Supplementary Data Figure S4). However, overexpression or deletion of phe did not improve indole tolerance and HPLC analysis revealed decreasing indole and increasing tryptophan concentrations, whereas no further aromatic compounds were detected by HPLC or GC-MS analysis (Figure S6). Increased phe expression upon increasing indole concentrations may be due to regulation as we speculate that indole might serve as inducer of PheR.

Adaptive laboratory evolution to increase indole tolerance led to the discovery of Cg3388/IhtR as indole, hydroquinone, and 1,2,4-trihydroxybenzene responsive transcriptional regulator repressing transcription of the divergently transcribed iolT2-rhcM2D2 operon. IolT2 and IolT1 are known to import inositol, glucose, and fructose into the C. glutamicum cell [77,83], while import of xylose has 
only been found for IolT1 [84]. Transcription of iolT1 and the large iol operons are repressed by IolR, which is responsive to myo-inositol or a myo-inositol degradation product [85]. By contrast, inositol-dependent regulation of iolT2 has not yet been observed and inositol was shown here not to interfere with DNA binding of Cg3388/IhtR (see above). The iolT2-rhcM2D2 operon also encodes catechol 1,2-monooxygenase and maleylacetate reductase enzymes. Paralogs are encoded by the rol operon (cg1112-cg1115), which is negatively regulated by RolR and required for catabolism of resorcinol and 2,4-dihydroxybenzoate [24,30]. Although the iolT2-rhcM2D2 operon is not required for growth with resorcinol, it is, however, transcribed in the presence of resorcinol [23]. Resorcinol did not function as inducer of $\mathrm{Cg} 3388 / \mathrm{IhtR}$ (Figure 6), but the intermediate of resorcinol degradation 1,2,4-trihydroxybenzene was the most effective Cg3388/IhtR inducer ( $\geq 0.05 \mathrm{mM}$ ) (Figure 6). Possibly, $\mathrm{Cg} 3388 / \mathrm{IhtR}$ is important to regulate the iolT2-rhcM2D2 operon, which is derepressed in the presence of 1,2,4-trihydroxybenzene or aromatic compounds other than the inducers of RolR resorcinol and hydroxyquinol that lead to 1,2,4-trihydroxybenzene. Indole only induced the iolT2-rhcM2D2 operon, but not the rol operon; thus, it is not an inducer of RolR. Induction of the iolT2-rhcM2D2 operon by indole may be a metabolic burden, slowing growth in its presence or indole may be converted to a growth inhibitory compound by catechol 1,2-monooxygenase RhcM2 and/or maleylacetate reductase RhcD2. In the latter case, this compound may be synthesized intracellularly, but we did not obtain evidence for its accumulation in the culture medium. The nature of this putative indole-derived inhibitor remains elusive.

Supplementary Materials: Supplementary materials can be found at http://www.mdpi.com/2076-2607/8/12/1945/s1.

Author Contributions: T.W. constructed strains. T.W., K.H.V., S.G., A.B.K., J.P., T.B. and K.C. performed the experiments. T.W., C.R. and T.B. performed bioinformatics analysis. T.W., K.H.V., S.G., A.B.K., K.C. and V.F.W. analyzed the data. T.B., K.C. and V.F.W. provided resources. T.W., A.B.K., K.C. and J.P. drafted the manuscript. T.W. and V.F.W. reviewed and edited. V.F.W. finalized the manuscript. All authors have read and agreed to the published version of the manuscript.

Funding: Funding by ERACoBiotech via grant INDIE (BMEL 22023517) is gratefully acknowledged. Support for the Article Processing Charge by the Deutsche Forschungsgemeinschaft and the Open Access Publication Fund of Bielefeld University is acknowledged.

Acknowledgments: We want to thank Isabel Conze for cloning expression plasmids and Bastian Blombach and Michael Bott for strain provision.

Conflicts of Interest: The authors declare no conflict of interest. The funders had no role in the design of the study, in the collection, analyses, or interpretation of data; in the writing of the manuscript or in the decision to publish the results.

Data Availability: The mapped genome sequencing data is available via BioProject: PRJNA669552 and the transcriptomic data is available via NCBI GEO accession identifiers GSE159887 and GSE159888.

\section{References}

1. Berger, R.G. (Ed.) Flavours and Fragrances: Chemistry, Bioprocessing and Sustainability; Springer: Berlin/Heidelberg, Germany, 2007; ISBN 978-3-540-49338-9. [CrossRef]

2. Chandra, S.; Askari, K.; Kumari, M. Optimization of indole acetic acid production by isolated bacteria from Stevia rebaudiana rhizosphere and its effects on plant growth. J. Genet. Eng. Biotechnol. 2018, 16, 581-586. [CrossRef]

3. Fabara, A.N.; Fraaije, M.W. An overview of microbial indigo-forming enzymes. Appl. Microbiol. Biotechnol. 2020, 104, 925-933. [CrossRef]

4. Lee, J.-H.; Wood, T.K.; Lee, J. Roles of indole as an interspecies and interkingdom signaling molecule. Trends Microbiol. 2015, 23, 707-718. [CrossRef]

5. Zarkan, A.; Liu, J.; Matuszewska, M.; Gaimster, H.; Summers, D.K. Local and universal action: The paradoxes of indole signalling in bacteria. Trends Microbiol. 2020, 28, 566-577. [CrossRef] [PubMed]

6. Frey, M.; Schullehner, K.; Dick, R.; Fiesselmann, A.; Gierl, A. Benzoxazinoid biosynthesis, a model for evolution of secondary metabolic pathways in plants. Phytochemistry 2009, 70, 1645-1651. [CrossRef] 
7. Snell, E.E. Tryptophanase: Structure, catalytic activities, and mechanism of action. In Advances in Enzymology and Related Areas of Molecular Biology; John Wiley \& Sons, Ltd.: Hoboken, NJ, USA, 2006; pp. 287-333, ISBN 978-0-470-12287-7. [CrossRef]

8. Yanofsky, C.; Horn, V.; Gollnick, P. Physiological studies of tryptophan transport and tryptophanase operon induction in Escherichia coli. J. Bacteriol. 1991, 173, 6009-6017. [CrossRef]

9. Vega, N.M.; Allison, K.R.; Khalil, A.S.; Collins, J.J. Signaling-mediated bacterial persister formation. Nat. Chem. Biol. 2012, 8, 431-433. [CrossRef] [PubMed]

10. Piñero-Fernandez, S.; Chimerel, C.; Keyser, U.F.; Summers, D.K. Indole transport across Escherichia coli membranes. J. Bacteriol. 2011, 193, 1793-1798. [CrossRef] [PubMed]

11. Kawamura-Sato, K.; Shibayama, K.; Horii, T.; Iimuma, Y.; Arakawa, Y.; Ohta, M. Role of multiple efflux pumps in Escherichia coli in indole expulsion. FEMS Microbiol. Lett. 1999, 179, 345-352. [CrossRef]

12. Ma, Q.; Zhang, X.; Qu, Y. Biodegradation and biotransformation of indole: Advances and perspectives. Front. Microbiol. 2018, 9, 2625. [CrossRef]

13. Arora, P.K.; Sharma, A.; Bae, H. Microbial degradation of indole and its derivatives. J. Chem. 2015, 2015, 129159. [CrossRef]

14. Sadauskas, M.; Vaitekūnas, J.; Gasparavičiūtè, R.; Meškys, R. Indole biodegradation in Acinetobacter sp. strain O153: Genetic and biochemical characterization. Appl. Environ. Microbiol. 2017, 83. [CrossRef] [PubMed]

15. Qu, Y.; Ma, Q.; Liu, Z.; Wang, W.; Tang, H.; Zhou, J.; Xu, P. Unveiling the biotransformation mechanism of indole in a Cupriavidus sp. strain. Mol. Microbiol. 2017, 106, 905-918. [CrossRef] [PubMed]

16. Kim, J.; Hong, H.; Heo, A.; Park, W. Indole toxicity involves the inhibition of adenosine triphosphate production and protein folding in Pseudomonas putida. FEMS Microbiol. Lett. 2013, 343, 89-99. [CrossRef]

17. Lee, J.; Zhang, X.-S.; Hegde, M.; Bentley, W.E.; Jayaraman, A.; Wood, T.K. Indole cell signaling occurs primarily at low temperatures in Escherichia coli. ISME J. 2008, 2, 1007-1023. [CrossRef]

18. Shen, X.-H.; Zhou, N.-Y.; Liu, S.-J. Degradation and assimilation of aromatic compounds by Corynebacterium glutamicum: Another potential for applications for this bacterium? Appl. Microbiol. Biotechnol. 2012, 95, 77-89. [CrossRef]

19. Lee, S.Y.; Le, T.-H.; Chang, S.-T.; Park, J.-S.; Kim, Y.-H.; Min, J. Utilization of phenol and naphthalene affects synthesis of various amino acids in Corynebacterium glutamicum. Curr. Microbiol. 2010, 61, 596-600. [CrossRef]

20. Chao, H.; Zhou, N.-Y. GenR, an IclR-type regulator, activates and represses the transcription of gen genes involved in 3-hydroxybenzoate and gentisate catabolism in Corynebacterium glutamicum. J. Bacteriol. 2013, 195, 1598-1609. [CrossRef]

21. Kallscheuer, N.; Vogt, M.; Kappelmann, J.; Krumbach, K.; Noack, S.; Bott, M.; Marienhagen, J. Identification of the phd gene cluster responsible for phenylpropanoid utilization in Corynebacterium glutamicum. Appl. Microbiol. Biotechnol. 2016, 100, 1871-1881. [CrossRef]

22. Merkens, H.; Beckers, G.; Wirtz, A.; Burkovski, A. Vanillate metabolism in Corynebacterium glutamicum. Curr. Microbiol. 2005, 51, 59-65. [CrossRef]

23. Huang, Y.; Zhao, K.-X.; Shen, X.-H.; Chaudhry, M.T.; Jiang, C.-Y.; Liu, S.-J. Genetic characterization of the resorcinol catabolic pathway in Corynebacterium glutamicum. Appl. Environ. Microbiol. 2006, 72, 7238-7245. [CrossRef]

24. Li, T.; Zhao, K.; Huang, Y.; Li, D.; Jiang, C.-Y.; Zhou, N.; Fan, Z.; Liu, S.-J. The TetR-type transcriptional repressor RolR from Corynebacterium glutamicum regulates resorcinol catabolism by binding to a unique operator, rolO. Appl. Environ. Microbiol. 2012, 78, 6009-6016. [CrossRef] [PubMed]

25. Li, T.; Chen, X.; Chaudhry, M.T.; Zhang, B.; Jiang, C.-Y.; Liu, S.-J. Genetic characterization of 4-cresol catabolism in Corynebacterium glutamicum. J. Biotechnol. 2014, 192, 355-365. [CrossRef] [PubMed]

26. Du, L.; Ma, L.; Qi, F.; Zheng, X.; Jiang, C.; Li, A.; Wan, X.; Liu, S.-J.; Li, S. Characterization of a unique pathway for 4-Cresol catabolism initiated by phosphorylation in Corynebacterium glutamicum. J. Biol. Chem. 2016, 291, 6583-6594. [CrossRef] [PubMed]

27. Kubota, T.; Tanaka, Y.; Takemoto, N.; Hiraga, K.; Yukawa, H.; Inui, M. Identification and expression analysis of a gene encoding a shikimate transporter of Corynebacterium glutamicum. Microbiology 2015, 161, 254-263. [CrossRef]

28. Lee, J.-H.; Wendisch, V.F. Biotechnological production of aromatic compounds of the extended shikimate pathway from renewable biomass. J. Biotechnol. 2017, 257, 211-221. [CrossRef] 
29. Shen, X.; Liu, S. Key enzymes of the protocatechuate branch of the $\beta$-ketoadipate pathway for aromatic degradation in Corynebacterium glutamicum. Sci. China C Life Sci. 2005, 48, 241-249. [CrossRef]

30. Li, D.-F.; Zhang, N.; Hou, Y.-J.; Huang, Y.; Hu, Y.; Zhang, Y.; Liu, S.-J.; Wang, D.-C. Crystal structures of the transcriptional repressor RolR reveals a novel recognition mechanism between inducer and regulator. PLoS ONE 2011, 6, e19529. [CrossRef]

31. Feng, J.; Che, Y.; Milse, J.; Yin, Y.-J.; Liu, L.; Rückert, C.; Shen, X.-H.; Qi, S.-W.; Kalinowski, J.; Liu, S.-J. The gene $n c g l 2918$ encodes a novel maleylpyruvate isomerase that needs mycothiol as cofactor and links mycothiol biosynthesis and gentisate assimilation in Corynebacterium glutamicum. J. Biol. Chem. 2006, 281, 10778-10785. [CrossRef]

32. Shang, X.; Zhang, Y.; Zhang, G.; Chai, X.; Deng, A.; Liang, Y.; Wen, T. Characterization and molecular mechanism of AroP as an aromatic amino acid and histidine transporter in Corynebacterium glutamicum. J. Bacteriol. 2013, 195, 5334-5342. [CrossRef]

33. Zhao, Z.; Ding, J.-Y.; Li, T.; Zhou, N.-Y.; Liu, S.-J. The ncgl1108 (PheP (Cg)) gene encodes a new L-Phe transporter in Corynebacterium glutamicum. Appl. Microbiol. Biotechnol. 2011, 90, 2005-2013. [CrossRef]

34. Xu, Y.; Wang, S.-H.; Chao, H.-J.; Liu, S.-J.; Zhou, N.-Y. Biochemical and molecular characterization of the gentisate transporter GenK in Corynebacterium glutamicum. PLoS ONE 2012, 7, e38701. [CrossRef] [PubMed]

35. Chaudhry, M.T.; Huang, Y.; Shen, X.-H.; Poetsch, A.; Jiang, C.-Y.; Liu, S.-J. Genome-wide investigation of aromatic acid transporters in Corynebacterium glutamicum. Microbiology 2007, 153, 857-865. [CrossRef] [PubMed]

36. Teramoto, H.; Inui, M.; Yukawa, H. Regulation of expression of genes involved in quinate and shikimate utilization in Corynebacterium glutamicum. Appl. Environ. Microbiol. 2009, 75, 3461-3468. [CrossRef]

37. Brinkrolf, K.; Brune, I.; Tauch, A. Transcriptional regulation of catabolic pathways for aromatic compounds in Corynebacterium glutamicum. Genet. Mol. Res. 2006, 5, 773-789. [PubMed]

38. Chen, X.; Kohl, T.A.; Rückert, C.; Rodionov, D.A.; Li, L.-H.; Ding, J.-Y.; Kalinowski, J.; Liu, S.-J. Phenylacetic acid catabolism and its transcriptional regulation in Corynebacterium glutamicum. Appl. Environ. Microbiol. 2012, 78, 5796-5804. [CrossRef]

39. Heravi, K.M.; Lange, J.; Watzlawick, H.; Kalinowski, J.; Altenbuchner, J. Transcriptional Regulation of the vanillate utilization genes (vanABK Operon) of Corynebacterium glutamicum by VanR, a PadR-like repressor. J. Bacteriol. 2015, 197, 959-972. [CrossRef]

40. Zhao, K.-X.; Huang, Y.; Chen, X.; Wang, N.-X.; Liu, S.-J. PcaO positively regulates $p c a H G$ of the beta-ketoadipate pathway in Corynebacterium glutamicum. J. Bacteriol. 2010, 192, 1565-1572. [CrossRef]

41. Kubota, T.; Tanaka, Y.; Takemoto, N.; Watanabe, A.; Hiraga, K.; Inui, M.; Yukawa, H. Chorismate-dependent transcriptional regulation of quinate/shikimate utilization genes by LysR-type transcriptional regulator QsuR in Corynebacterium glutamicum: Carbon flow control at metabolic branch point. Mol. Microbiol. 2014, 92, 356-368. [CrossRef]

42. Purwanto, S.H.; Kang, M.-S.; Ferrer, L.; Han, S.-S.; Lee, J.-Y.; Kim, H.-S.; Lee, J.-H. Rational engineering of the shikimate and related pathways in Corynebacterium glutamicum for 4-hydroxybenzoate production. J. Biotechnol. 2018, 282, 92-100. [CrossRef]

43. Kitade, Y.; Hashimoto, R.; Suda, M.; Hiraga, K.; Inui, M. Production of 4-hydroxybenzoic acid by an aerobic growth-arrested bioprocess using metabolically engineered Corynebacterium glutamicum. Appl. Environ. Microbiol. 2018, 84, e02587-17. [CrossRef] [PubMed]

44. Veldmann, K.H.; Dachwitz, S.; Risse, J.M.; Lee, J.-H.; Sewald, N.; Wendisch, V.F. Bromination of L-tryptophan in a fermentative process with Corynebacterium glutamicum. Front. Bioeng. Biotechnol. 2019, 7. [CrossRef]

45. Veldmann, K.H.; Minges, H.; Sewald, N.; Lee, J.-H.; Wendisch, V.F. Metabolic engineering of Corynebacterium glutamicum for the fermentative production of halogenated tryptophan. J. Biotechnol. 2019, 291, 7-16. [CrossRef] [PubMed]

46. Walter, T.; Al Medani, N.; Burgardt, A.; Cankar, K.; Ferrer, L.; Kerbs, A.; Lee, J.-H.; Mindt, M.; Risse, J.M.; Wendisch, V.F. Fermentative $N$-Methylanthranilate production by engineered Corynebacterium glutamicum. Microorganisms 2020, 8, 866. [CrossRef] [PubMed]

47. Luo, Z.W.; Cho, J.S.; Lee, S.Y. Microbial production of methyl anthranilate, a grape flavor compound. Proc. Natl. Acad. Sci. USA 2019, 116, 10749-10756. [CrossRef] [PubMed] 
48. Milke, L.; Mutz, M.; Marienhagen, J. Synthesis of the character impact compound raspberry ketone and additional flavoring phenylbutanoids of biotechnological interest with Corynebacterium glutamicum. Microb. Cell Fact 2020, 19, 92. [CrossRef]

49. Hanahan, D. Studies on transformation of Escherichia coli with plasmids. J. Mol. Biol. 1983, 166, 557-580. [CrossRef]

50. Green, M.R.; Sambrook, J.; Sambrook, J. Molecular Cloning: A Laboratory Manual; Cold Spring Harbor Laboratory Press: Cold Spring Harbor, NY, USA, 2012; ISBN 978-1-936113-41-5.

51. Eggeling, L.; Bott, M. Handbook of Corynebacterium glutamicum; CRC Press: Boca Raton, FL, USA, 2005; ISBN 978-1-4200-3969-6.

52. Baumgart, M.; Unthan, S.; Kloß, R.; Radek, A.; Polen, T.; Tenhaef, N.; Müller, M.F.; Küberl, A.; Siebert, D.; Brühl, N.; et al. Corynebacterium glutamicum Chassis C1*: Building and besting a bovel platform host for synthetic biology and industrial biotechnology. ACS Synth. Biol. 2018, 7, 132-144. [CrossRef]

53. Wennerhold, J.; Bott, M. The DtxR regulon of Corynebacterium glutamicum. J. Bacteriol. 2006, 188, $2907-2918$. [CrossRef]

54. Bussmann, M.; Baumgart, M.; Bott, M. RosR (Cg1324), a hydrogen peroxide-sensitive MarR-type transcriptional regulator of Corynebacterium glutamicum. J. Biol. Chem. 2010, 285, 29305-29318. [CrossRef]

55. Lange, J.; Münch, E.; Müller, J.; Busche, T.; Kalinowski, J.; Takors, R.; Blombach, B. Deciphering the adaptation of Corynebacterium glutamicum in transition from aerobiosis via microaerobiosis to anaerobiosis. Genes 2018, 9, 297. [CrossRef]

56. Simon, R.; Priefer, U.; Pühler, A. A broad host range mobilization system for in vivo genetic engineering: Transposon mutagenesis in gram negative bacteria. Bio/Technology 1983, 1, 784-791. [CrossRef]

57. Studier, F.W.; Moffatt, B.A. Use of bacteriophage T7 RNA polymerase to direct selective high-level expression of cloned genes. J. Mol. Biol. 1986, 189, 113-130. [CrossRef]

58. Schäfer, A.; Tauch, A.; Jäger, W.; Kalinowski, J.; Thierbach, G.; Pühler, A. Small mobilizable multi-purpose cloning vectors derived from the Escherichia coli plasmids pK18 and pK19: Selection of defined deletions in the chromosome of Corynebacterium glutamicum. Gene 1994, 145, 69-73. [CrossRef]

59. Salis, H.M.; Mirsky, E.A.; Voigt, C.A. Automated design of synthetic ribosome binding sites to control protein expression. Nat. Biotechnol. 2009, 27, 946-950. [CrossRef] [PubMed]

60. Langmead, B.; Trapnell, C.; Pop, M.; Salzberg, S.L. Ultrafast and memory-efficient alignment of short DNA sequences to the human genome. Genome Biol. 2009, 10, R25. [CrossRef]

61. Anders, S.; Huber, W. Differential expression analysis for sequence count data. Genome Biol. 2010, 11, R106. [CrossRef]

62. Love, M.I.; Huber, W.; Anders, S. Moderated estimation of fold change and dispersion for RNA-seq data with DESeq2. Genome Biol. 2014, 15, 550. [CrossRef]

63. Hilker, R.; Stadermann, K.B.; Schwengers, O.; Anisiforov, E.; Jaenicke, S.; Weisshaar, B.; Zimmermann, T.; Goesmann, A. ReadXplorer 2-Detailed read mapping analysis and visualization from one single source. Bioinformatics 2016, 32, 3702-3708. [CrossRef]

64. Hilker, R.; Stadermann, K.B.; Doppmeier, D.; Kalinowski, J.; Stoye, J.; Straube, J.; Winnebald, J.; Goesmann, A. ReadXplorer-Visualization and analysis of mapped sequences. Bioinformatics 2014, 30, 2247-2254. [CrossRef]

65. Bustin, S.A.; Benes, V.; Garson, J.A.; Hellemans, J.; Huggett, J.; Kubista, M.; Mueller, R.; Nolan, T.; Pfaffl, M.W.; Shipley, G.L.; et al. The MIQE guidelines: Minimum information for publication of quantitative real-time PCR experiments. Clin. Chem. 2009, 55, 611-622. [CrossRef]

66. Higuchi, R.; Dollinger, G.; Walsh, P.S.; Griffith, R. Simultaneous amplification and detection of specific DNA sequences. Bio/Technology 1992, 10, 413-417. [CrossRef]

67. Seemann, T. Snippy: Fast Bacterial Variant Calling from NGS Reads. Available online: https://github.com/ tseemann/snippy (accessed on 17 January 2017).

68. Henke, N.A.; Heider, S.A.E.; Hannibal, S.; Wendisch, V.F.; Peters-Wendisch, P. Isoprenoid pyrophosphate-dependent transcriptional regulation of carotenogenesis in Corynebacterium glutamicum. Front. Microbiol. 2017, 8, 633. [CrossRef]

69. Müller, F.; Rapp, J.; Hacker, A.-L.; Feith, A.; Takors, R.; Blombach, B. $\mathrm{CO}_{2} / \mathrm{HCO}_{3}$ - accelerates iron reduction through phenolic compounds. mBio 2020, 11. [CrossRef]

70. Erdmann, A.; Weil, B.; Krämer, R. Lysine secretion by wild-type Corynebacterium glutamicum triggered by dipeptide uptake. Microbiology 1993, 139, 3115-3122. [CrossRef] 
71. Lubitz, D.; Jorge, J.M.P.; Pérez-García, F.; Taniguchi, H.; Wendisch, V.F. Roles of export genes $\operatorname{cgmA}$ and $l y s E$ for the production of L-arginine and L-citrulline by Corynebacterium glutamicum. Appl. Microbiol. Biotechnol. 2016, 100, 8465-8474. [CrossRef]

72. Ni, Y.; Shi, F.; Wang, N. Specific $\gamma$-aminobutyric acid decomposition by gabP and gabT under neutral $\mathrm{pH}$ in recombinant Corynebacterium glutamicum. Biotechnol. Lett. 2015, 37, 2219-2227. [CrossRef]

73. Lee,J.-Y.; Park, J.-S.; Kim, H.-J.; Kim, Y.; Lee, H.-S. Corynebacterium glutamicum whcB, a stationary phase-specific regulatory gene. FEMS Microbiol. Lett. 2012, 327, 103-109. [CrossRef] [PubMed]

74. Küberl, A.; Mengus-Kaya, A.; Polen, T.; Bott, M. The iron deficiency response of Corynebacterium glutamicum and a link to thiamine biosynthesis. Appl. Environ. Microbiol. 2020, 86. [CrossRef] [PubMed]

75. Frunzke, J.; Bramkamp, M.; Schweitzer, J.-E.; Bott, M. Population heterogeneity in Corynebacterium glutamicum ATCC 13032 caused by prophage CGP3. J. Bacteriol. 2008, 190, 5111-5119. [CrossRef]

76. Netzer, R.; Krause, M.; Rittmann, D.; Peters-Wendisch, P.G.; Eggeling, L.; Wendisch, V.F.; Sahm, H. Roles of pyruvate kinase and malic enzyme in Corynebacterium glutamicum for growth on carbon sources requiring gluconeogenesis. Arch. Microbiol. 2004, 182, 354-363. [CrossRef] [PubMed]

77. Lindner, S.N.; Seibold, G.M.; Krämer, R.; Wendisch, V.F. Impact of a new glucose utilization pathway in amino acid-producing Corynebacterium glutamicum. Bioeng. Bugs 2011, 2, 291-295. [CrossRef] [PubMed]

78. Schröder, J.; Tauch, A. Transcriptional regulation of gene expression in Corynebacterium glutamicum: The role of global, master and local regulators in the modular and hierarchical gene regulatory network. FEMS Microbiol. Rev. 2010, 34, 685-737. [CrossRef]

79. Brune, I.; Werner, H.; Hüser, A.T.; Kalinowski, J.; Pühler, A.; Tauch, A. The DtxR protein acting as dual transcriptional regulator directs a global regulatory network involved in iron metabolism of Corynebacterium glutamicum. BMC Genom. 2006, 7, 21. [CrossRef]

80. Morosov, X.; Davoudi, C.-F.; Baumgart, M.; Brocker, M.; Bott, M. The copper-deprivation stimulon of Corynebacterium glutamicum comprises proteins for biogenesis of the actinobacterial cytochrome bc1-aa3 supercomplex. J. Biol. Chem. 2018, 293, 15628-15640. [CrossRef]

81. Chen, C.; Zhang, Y.; Xu, L.; Zhu, K.; Feng, Y.; Pan, J.; Si, M.; Zhang, L.; Shen, X. Transcriptional control of the phenol hydroxylase gene phe of Corynebacterium glutamicum by the AraC-type regulator PheR. Microbiol. Res. 2018, 209, 14-20. [CrossRef]

82. Xiao, X.; Si, M.; Yang, Z.; Zhang, Y.; Guan, J.; Chaudhry, M.T.; Wang, Y.; Shen, X. Molecular characterization of a eukaryotic-like phenol hydroxylase from Corynebacterium glutamicum. J. Gen. Appl. Microbiol. 2015, 61, 99-107. [CrossRef]

83. Bäumchen, C.; Krings, E.; Bringer, S.; Eggeling, L.; Sahm, H. Myo-inositol facilitators IolT1 and IolT2 enhance D-mannitol formation from D-fructose in Corynebacterium glutamicum. FEMS Microbiol. Lett. 2009, 290, 227-235. [CrossRef]

84. Brüsseler, C.; Radek, A.; Tenhaef, N.; Krumbach, K.; Noack, S.; Marienhagen, J. The myo-inositol/proton symporter IolT1 contributes to D-xylose uptake in Corynebacterium glutamicum. Bioresour. Technol. 2018, 249, 953-961. [CrossRef]

85. Klaffl, S.; Brocker, M.; Kalinowski, J.; Eikmanns, B.J.; Bott, M. Complex Regulation of the phosphoenolpyruvate carboxykinase gene $p c k$ and characterization of its GntR-type regulator IolR as a repressor of myo-Inositol utilization genes in Corynebacterium glutamicum. J. Bacteriol. 2013, 195, 4283-4296. [CrossRef]

Publisher's Note: MDPI stays neutral with regard to jurisdictional claims in published maps and institutional affiliations.

(C) 2020 by the authors. Licensee MDPI, Basel, Switzerland. This article is an open access article distributed under the terms and conditions of the Creative Commons Attribution (CC BY) license (http://creativecommons.org/licenses/by/4.0/). 